Research Paper

\title{
Simultaneous degradation of ciprofloxacin, amoxicillin, sulfathiazole and sulfamethazine, and disinfection of hospital effluent after biological treatment via photo-Fenton process under ultraviolet germicidal irradiation
}

\author{
João A. Lima Perini ${ }^{\mathrm{a}, *}$, Adriano L. Tonetti ${ }^{\mathrm{b}}$, Cristiane Vidal $^{\mathrm{c}}$, Cassiana C. Montagner ${ }^{\mathrm{c}}$, \\ Raquel F. Pupo Nogueira ${ }^{a}$
}

${ }^{a}$ Department of Analytical Chemistry, Institute of Chemistry of Araraquara UNESP, São Paulo State University, P.O. Box 355, 14801-970, Araraquara, SP, Brazil

b School of Civil Engineering, Architecture and Urban Design-FEC, UNICAMP, University of Campinas, P.O. Box 6021, 13083-852, Campinas, SP, Brazil

${ }^{\mathrm{c}}$ Department of Analytical Chemistry, Institute of Chemistry of Campinas, UNICAMP, University of Campinas, P.O. Box 6154, 13083-970, Campinas, SP, Brazil

\section{A R T I C L E I N F O}

\section{Keywords:}

Anaerobic treatment

Hydroxyl radical

Photolysis

Pharmaceuticals

Bacterial disinfection

\begin{abstract}
A B S T R A C T
A UVC-assisted photo-Fenton process was applied to hospital wastewater that had been submitted to anaerobic treatment. Low iron $\left(10 \mu \mathrm{M} ; 0.56 \mathrm{mg} \mathrm{L}^{-1}\right)$ and $\mathrm{H}_{2} \mathrm{O}_{2}\left(500 \mu \mathrm{M} ; 17 \mathrm{mg} \mathrm{L}^{-1}\right)$ concentrations were used at the natural $\mathrm{pH}$ of the effluent $(\mathrm{pH} \approx 7.4)$. Citric acid was employed as a complexation agent, at a 1:1 ratio, in order to maintain $\mathrm{Fe}^{3+}$ soluble at this $\mathrm{pH}$, avoiding extra procedures and costs associated with acidification/basification of the final effluent. The anaerobic process quantitatively reduced the biochemical oxygen demand $\left(\mathrm{BOD}_{5}\right)$, chemical oxygen demand (COD) and total organic carbon (TOC), with low removal of antibiotics present in the wastewater. Degradation of the antibiotics ciprofloxacin, amoxicillin, sulfathiazole, and sulfamethazine was studied by spiking the anaerobic effluent at initial concentrations of $200 \mu \mathrm{L} \mathrm{L}^{-1}$. The antibiotics were efficiently degraded (80-95\%) using UVC radiation alone, although under this condition, no DOC removal was observed after $90 \mathrm{~min}$. Further additions of $\mathrm{H}_{2} \mathrm{O}_{2}$ and iron citrate increased the degradation rate constant $\left(k_{o b s}\right)$, and $8 \%$ of DOC was removed. A lower $\mathrm{pH}$ resulted in higher $k_{o b s}$, although this was not essential for application of the photo-Fenton process. Irradiation with a germicidal lamp resulted in greater degradation of the antibiotics, compared to use of a black light lamp or sunlight, since the overall degradation was influenced by photolysis of the antibiotics, photolysis of $\mathrm{H}_{2} \mathrm{O}_{2}$, and the Fenton reaction. The photo-Fenton treatment could also be applied directly to the raw hospital wastewater, since no significant difference in degradation of the antibiotics was observed, compared to the anaerobic effluent. The photo-Fenton process under UVA and solar radiation reduced total coliforms and E. coli after $90 \mathrm{~min}$. However, quantitative disinfection of these bacteria present in the Hospital effluent was only accomplished under UVC radiation.
\end{abstract}

\section{Introduction}

Antibiotics are the pharmaceuticals with the highest prescription and consumption rates worldwide, in both human and veterinary medicine, and are mainly used to treat bacterial infections. Besides their medicinal use, they are also employed as growth promoters in livestock animal production [1]. However, concerns about antibiotics include their potential collateral effects on human health and aquatic ecosystems $[2,3]$, and the emergence of resistant bacteria $[2,4,5]$.

Most antibiotics are poorly metabolized in the human body $[2,6]$, with the parent compounds being excreted and often transported to wastewater treatment plants (WWTPs) in sewage systems. In the case of hospital wastewater, the loads of organic material are similar to those in urban wastewater, which has led to the discharge of this effluent into municipal sewage systems without any prior treatment. However, the average concentrations of various drugs in hospital effluents can be 2-150 times higher than the concentrations found in urban wastewater, as reported by Verlicch et al. [7]. Furthermore, hospitals are important sources of pathogens found in urban wastewaters $[2,8,9]$.

Therefore, the treatment of hospital effluents before their disposal into urban wastewater systems is very important in order to avoid problems of contamination and inhibition of biomass growth in conventional WWTPs, which are usually based on biological treatments that are unable to completely remove pharmaceutical products including antibiotics and their metabolites [10]. The removal rates of antibiotics in WWTPs are reported to range from 80 to $90 \%$, and the removal is mainly due to

\footnotetext{
* Corresponding author

E-mail address: joaoperini@gmail.com (J.A.L. Perini).
} 
adsorption on the sludge, rather than degradation [11-16].

An additional consideration is that there are several disadvantages associated with the traditional methods employed for the disinfection of water/wastewater, such as chlorination or ozonation. These include the production of toxic and carcinogenic halogenated byproducts, due to the reaction of chlorine with natural organic matter (NOM) and pharmaceutical compounds, as well as the high cost of $\mathrm{O}_{3}$ and the quantities required, which make it unattractive for disinfection purposes $[17,18]$.

There is a clear need to develop suitable methods for the treatment of hospital effluent, using new and improved technologies, in order to minimize undesirable effects in the environment. The use of advanced oxidation processes (AOPs) is an attractive option that enables the removal of non-biodegradable/toxic compounds and the inactivation of a wide range of microorganisms. AOPs are based on the generation of hydroxyl radicals $(\cdot \mathrm{OH})$ from reactions involving oxidants such as hydrogen peroxide or ozone, UV-vis irradiation, and catalysts including metal ions or semiconductors. The Fenton process is an AOP in which $\mathrm{OH}$ is generated from a mixture of $\mathrm{H}_{2} \mathrm{O}_{2}$ and $\mathrm{Fe}^{2+}$ in an acid medium (Eq. (1)). It can be applied before biological treatments, with the consequent partial oxidation of organic compounds assisting their biodegradation, or after biological treatments, in order to degrade recalcitrant compounds [19]. This process can be enhanced by UV-vis radiation (the so-called photo-Fenton process), accelerating the photoreduction of $\mathrm{Fe}^{3+}$ to $\mathrm{Fe}^{2+}$ and establishing an $\mathrm{Fe}(\mathrm{II}) / \mathrm{Fe}(\mathrm{III})$ cycle in the Fenton reaction, besides generating extra $\cdot \mathrm{OH}$ (Eq. (2)) [20].

$\mathrm{Fe}^{2+}+\mathrm{H}_{2} \mathrm{O}_{2} \rightarrow \mathrm{Fe}^{3+}+\cdot \mathrm{OH}+\mathrm{OH}^{-}\left(k=70 \mathrm{M}^{-1} \mathrm{~s}^{-1}\right)$

$\mathrm{Fe}(\mathrm{OH})^{2+}+h \nu \rightarrow \mathrm{Fe}^{2+}+\cdot \mathrm{OH}$

The main challenge in application of the photo-Fenton process for wastewater treatment is that it must operate at near-neutral $\mathrm{pH}$. The process is more effective under acid conditions (around $\mathrm{pH} 3$ ), due principally to iron precipitation above this $\mathrm{pH}$ [21]. However, the operational costs associated with acidification/basification of the wastewater to be treated are not attractive. The photo-Fenton reaction can be enhanced by the use of organic ligands such as oxalic or citric acid, among others. Organic Fe(III) complexes have higher molar absorption coefficients in the UV-vis region, and much higher quantum yields for generation of $\mathrm{Fe}^{2+}$, compared to iron aqua complexes [22-24]. Furthermore, $\mathrm{Fe}^{3+}$-polycarboxylate complexes can extend the $\mathrm{pH}$ range used in the Fenton reaction, allowing operation at near-neutral $\mathrm{pH}$ [25-28].

The use of AOPs for the degradation of pharmaceuticals has frequently been studied using ultrapure water and/or initial concentrations of analytes in the $\mathrm{mg} \mathrm{L}^{-1}$ range, which are far from the concentration range and conditions found in natural waters and wastewaters [29-33]. Furthermore, the UVC-assisted photo-Fenton process employing iron complexation agents, at neutral $\mathrm{pH}$, has not been evaluated for the treatment of hospital wastewater. Therefore, the focus of this work is to provide an option for the treatment of hospital wastewater containing high concentrations of organic carbon, pharmaceuticals, and pathogens. Firstly, the removal of $\mathrm{COD}, \mathrm{BOD}_{5}$, TOC, and other parameters from raw hospital wastewater (RHW) was performed using an upflow anaerobic filter. Secondly, the degradation of four antibiotics (ciprofloxacin, amoxicillin, sulfathiazole, and sulfamethazine) and bacterial disinfection (E. coli and total coliforms) in anaerobic hospital effluent (AHE) was carried out using UVC and a UVC-assisted photo-Fenton process with low concentrations of iron $\left(10 \mu \mathrm{M} ; 0.56 \mathrm{mg} \mathrm{L}^{-1}\right)$ and hydrogen peroxide $\left(500 \mu \mathrm{M} ; 17 \mathrm{mg} \mathrm{L}^{-1}\right)$, at the natural $\mathrm{pH}$ of the effluent $(\mathrm{pH} \approx 7.4$ ), avoiding the need for $\mathrm{pH}$ correction and making the process more attractive for practical applications.

\section{Material and methods}

\subsection{Reagents}

Ciprofloxacin hydrochloride monohydrate (CIP) $\left(\mathrm{C}_{17} \mathrm{H}_{18} \mathrm{FN}_{3} \mathrm{O}_{3} \cdot \mathrm{HCl} \cdot \mathrm{H}_{2} \mathrm{O}\right)$, amoxicillin trihydrate
$\left(\mathrm{C}_{16} \mathrm{H}_{19} \mathrm{~N}_{3} \mathrm{O}_{5} \mathrm{~S} \cdot 3 \mathrm{H}_{2} \mathrm{O}\right.$ ), sulfathiazole (STZ) (99\%) $\left(\mathrm{C}_{9} \mathrm{H}_{9} \mathrm{~N}_{3} \mathrm{O}_{2} \mathrm{~S}_{2}\right)$, sulfamethazine (SMZ) (99\%) $\left(\mathrm{C}_{12} \mathrm{H}_{14} \mathrm{~N}_{4} \mathrm{O}_{2} \mathrm{~S}\right.$ ), sulfadiazine (SDZ) (99\%) $\left(\mathrm{C}_{10} \mathrm{H}_{10} \mathrm{~N}_{4} \mathrm{O}_{2} \mathrm{~S}\right)$, sulfadoxin-d3 (S-d3) $\left(\mathrm{C}_{12} \mathrm{D}_{3} \mathrm{H}_{11} \mathrm{~N}_{4} \mathrm{O}_{4} \mathrm{~S}\right)$, and enrofloxacin-d5 hydrochloride (E-d5) $\left(\mathrm{C}_{19} \mathrm{D}_{5} \mathrm{H}_{17} \mathrm{FN}_{3} \mathrm{O}_{3} \cdot \mathrm{HCl}\right)$ (Table 1S) were obtained from Fluka (St. Louis, MO, USA). $\mathrm{Fe}\left(\mathrm{NO}_{3}\right)_{3} \cdot 9 \mathrm{H}_{2} \mathrm{O}$ (Mallinckrodt, Paris, KY, USA) was used to prepare aqueous $0.25 \mathrm{M}$ iron stock solution. $\mathrm{H}_{2} \mathrm{O}_{2}(30 \% \mathrm{w} / \mathrm{w})$ was from Synth (São Paulo, Brazil). Citric acid (Synth) was used as the iron ligand. 2,2'-bipyridyl and peroxidase (type II-A from horseradish, 1500 units/mg of solid) were purchased from Sigma-Aldrich (St. Louis, MO, USA). N,N-diethyl-1,4phenylene-diamine (DPD) was obtained from Fluka (Steinheim, Germany). 1,10-phenanthroline was obtained from Vetec (Rio de Janeiro, Brazil). A $1 \mathrm{M} \mathrm{H}_{2} \mathrm{SO}_{4}$ (Chemis, São Paulo, Brazil) solution was used for $\mathrm{pH}$ adjustment. Methanol and formic acid (HPLC grade) were purchased from J.T. Baker (Xalostoc, Mexico). Ultrapure water from a DG 500UF system (Gehaka, São Paulo, Brazil) was used for dilutions and for HPLC analysis.

\subsection{Hospital wastewater}

Wastewater from the University of Campinas hospital was firstly treated using an anaerobic process. As described by Tonon et al. [34], the system consisted of an upflow anaerobic filter filled with coconut shells (C. nucifera) (Fig. 1A). The hydraulic retention time of the filter was $9 \mathrm{~h}$ and the hydraulic loading rate was $200 \mathrm{~L} \mathrm{~m}^{-2}$ day $^{-1}$. The photo-Fenton process was applied to the effluent from the anaerobic treatment (AHE) with the aim of degrading the antibiotics. The following parameters of the RHW and AHE were determined: $\mathrm{pH}$, using a pH meter (1100 series, Oakton, Vernon Hills, IL, USA); total organic and inorganic carbon concentrations, using a TOC analyzer (TOC5000A, Shimadzu, Kyoto, Japan); turbidity (Q279P turbidimeter, Quimes, São Paulo, Brazil); conductivity and total dissolved solids (pH8b, pHtek, São Paulo, Brazil); and color, using a multi-parameter photometer (HI 83200, Hanna Instruments, Barueri, Brazil). The total iron concentrations in the RHW and AHE were determined by ICP-OES, using an Optima 8000 spectrometer (PerkinElmer, Waltham, MA, USA), after digestion of the samples with $\mathrm{H}_{2} \mathrm{O}_{2} / \mathrm{HNO}_{3}$. The variables COD, $\mathrm{BOD}_{5}, \mathrm{PO}_{4}{ }^{3-}$, and total nitrogen were determined according to the SMEWW (Standard Methods for the Examination of Water and Wastewater) reference methods 22 5220C, 225210 B, 224500 P-E, and 22 $4500 \mathrm{~N}_{\text {org }}$ B, respectively [35]. The concentrations of CIP, AMX, STZ, SMT, and SDZ in the RHW and AHE were determined by LC-MS/MS analysis, as described in Section 2.4. The efficiency of the photo-Fenton degradation of the antibiotics was evaluated by spiking the AHE with $200 \mu \mathrm{g} \mathrm{L}^{-1}$ of each antibiotic (CIP, AMX, STZ, and SMZ).

\subsection{Solid phase extraction (SPE)}

Solid phase extractions were performed in order to interrupt the degradation reactions and preconcentrate $(10 \times)$ the antibiotics prior to analysis, which was necessary for quantification at $\mu \mathrm{g} \mathrm{L}^{-1}$ levels. In the SPE, $\mathrm{Fe}^{2+}$ and $\mathrm{H}_{2} \mathrm{O}_{2}$ were discharged with the aqueous phase, without interacting with the solid phase, while the analytes were retained in the cartridge for subsequent elution, hence stopping the Fenton reaction.

In the photo-Fenton experiments, the extraction procedure was as described previously [36]. Oasis HLB cartridges (60 mg; Waters, Milford, MA, USA) were first conditioned with $5 \mathrm{~mL}$ of methanol, followed by $5 \mathrm{~mL}$ of water ( $\mathrm{pH} 2.5$ ). A $10 \mathrm{~mL}$ volume of aqueous sample ( $\mathrm{pH} 2.5$, with $0.1 \% \mathrm{w} / \mathrm{v}$ EDTA) was then percolated through the cartridge. Finally, the cartridge was washed with water $(\mathrm{pH} 7.0)$ and eluted with $1 \mathrm{~mL}$ of methanol. The eluate was filtered through a $0.45 \mu \mathrm{m}$ nylon membrane syringe filter (Millipore, Bedford, MA, USA) and was then analyzed using HPLC-DAD. No decreases of the antibiotics concentrations were observed after filtration. The average percentage recoveries of AMX, CIP, STZ, and SMZ from the hospital effluent were 


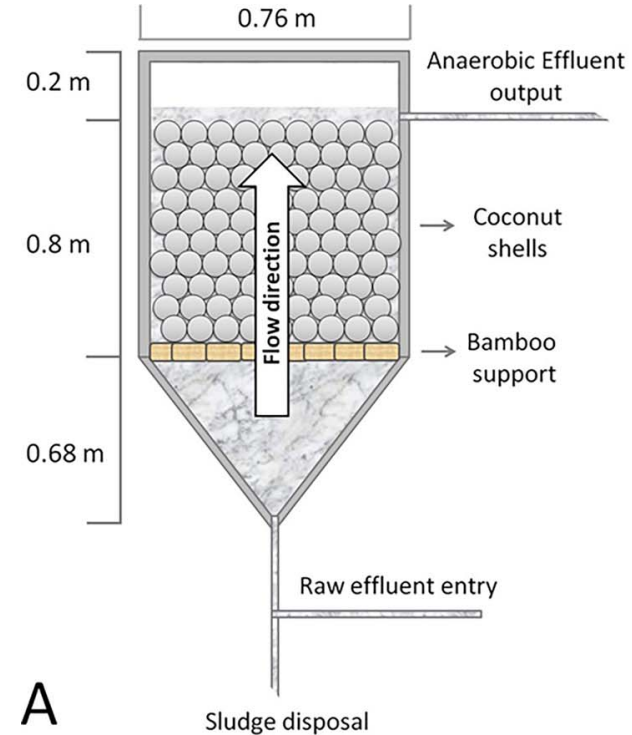

Fig. 1. Schematic illustrations of the anaerobic filter with coconut shells (A) and the reactor with UVC lamps used in the photo-Fenton process (B).

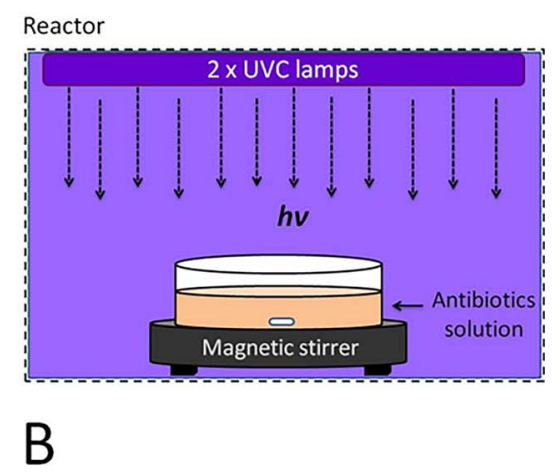

$68.2 \pm 12.8,103.8 \pm 15.2,92.3 \pm 8.5$, and $88.5 \pm 9.8$, respectively.

Preparation of the samples for quantification of the selected antibiotics in the RHW and AHE (without spiking) was performed using the same type of cartridge (Oasis HLB). However, in this case, $50 \mathrm{~mL}$ volumes of the effluents were first filtered through glass fiber filters (Sartorius-Stedim, Göttingen, Germany) and then through cellulose acetate filters $(0.45 \mu \mathrm{m})$, prior to SPE extraction. The samples were subsequently acidified to $\mathrm{pH} 2.5$, followed by the addition of EDTA $(0.1 \% \mathrm{w} / \mathrm{v})$ and sulfadoxin-d3 (S-d3), used as a surrogate. The cartridge was eluted twice with $5 \mathrm{~mL}$ methanol, evaporated with $\mathrm{N}_{2}$, recovered in $0.5 \mathrm{~mL}$ of $0.1 \% \mathrm{v} / \mathrm{v}$ formic acid: $\mathrm{MeOH}(90: 10, \mathrm{v} / \mathrm{v})$, with enrofloxacind5 (E-d5) as internal standard, and analyzed by LC-MS/MS. The recoveries of the surrogate (at $5 \mu \mathrm{g} \mathrm{L}^{-1}$ ) were $86 \pm 7 \%$ for the RHW and $63 \pm 7 \%$ for the AHE.

\subsection{Analytical methods}

The decays of the antibiotics concentrations during the photoFenton experiments were determined using a reversed-phase high performance liquid chromatography (HPLC) system (LC 20AT Prominence, Shimadzu, Kyoto, Japan) equipped with a diode array detector (DAD). Separation was achieved using a C-18 column (EVO Kinetex, $5 \mu \mathrm{m}, 150 \times 4.6 \mathrm{~mm}$; Phenomenex, Torrance, CA, USA) and guard column $(4 \times 3 \mathrm{~mm}$; Phenomenex $)$. The mobile phase was a mixture of methanol (A) and $0.1 \% \mathrm{v} / \mathrm{v}$ formic acid (B), at a flow rate of $0.5 \mathrm{~mL} \mathrm{~min}^{-1}$. Gradient elution was performed using $5 \% \mathrm{~A}$ and $95 \% \mathrm{~B}$ for $8.0 \mathrm{~min}$, followed by $15 \% \mathrm{~A}$ and $85 \% \mathrm{~B}$ for $12.0 \mathrm{~min}$, and an equilibration time of $3 \mathrm{~min}$. The injection volume was $40 \mu \mathrm{L}$ and the detection wavelengths were $275 \mathrm{~nm}$ (CIP, STZ, and SMZ) and $230 \mathrm{~nm}$ (AMX). The oven temperature was maintained at $40{ }^{\circ} \mathrm{C}$. Under these conditions, the retention times of AMX, STZ, CIP, and SMZ were 5.0, $13.8,15.7$, and $18.3 \mathrm{~min}$, respectively. The wastewater samples (AHE and RHW) were filtered through $0.45 \mu \mathrm{m}$ nylon membrane syringe filters before the HPLC-DAD analyses, and no decreases of the pharmaceutical concentrations were observed. The instrumental detection limits for AMX, CIP, STZ, and SMZ were 12, 31, 6.9, and $8.6 \mu \mathrm{g} \mathrm{L}^{-1}$, respectively.

Carboxylic acids were quantified in the AHE and RHW, as well as after the photo-Fenton process, using a Rezex ROA-Organic Acid $\mathrm{H}^{+}$ (8\%) ion-exclusion column $(8 \mu \mathrm{m}, 300 \times 7.8 \mathrm{~mm}$; Phenomenex, Torrance, CA, USA) in the same HPLC system, with detection at $210 \mathrm{~nm}$ and $2.5 \mathrm{mM} \mathrm{H}_{2} \mathrm{SO}_{4}$ as the mobile phase, at a flow rate of $0.5 \mathrm{~mL} \mathrm{~min}^{-1}$.

Quantification of the pharmaceuticals in the unspiked AHE and
RHW was performed using an LC-MS/MS system (1200 series, Agilent Technologyies, Santa Clara, CA, USA) equipped with a triple quadrupole QqQ 6410 B detector, an electrospray ionization source, and a StableBond C-18 column $(3.5 \mu \mathrm{m}, 2.1 \times 30 \mathrm{~mm}$; Agilent Technologies, Santa Clara, CA, USA). The mobile phase was methanol (A) and $0.1 \% \mathrm{v} /$ $\mathrm{v}$ formic acid (B), at a flow rate of $0.3 \mathrm{~mL} \mathrm{~min}^{-1}$. The gradient elution was from $5 \%$ to $30.5 \%$ A during $9.0 \mathrm{~min}$, followed by an increase to $65 \%$ A during $15 \mathrm{~min}$, a hold for $2 \mathrm{~min}$, and finally column re-equilibration during $6 \mathrm{~min}$. The retention times of AMX, SDZ, STZ, SMZ, S-d3, CIP, and E-d5 were 1.8, 2.2, 3.3, 6.2, 8.3, 8.6, and 9.2 min, respectively. The mass spectrometer ionization source was operated in positive mode. The capillary and fragmentation voltages were 4000 and $100 \mathrm{~V}$, respectively, the nebulizer pressure was $40 \mathrm{psi}$, and the temperature was $350^{\circ} \mathrm{C}$. The triple quadrupole mass spectrometer acquired data in multiple reaction monitoring mode. The mass spectrometer operating parameters and the performance of the LC-MS/MS method are described in Tables $2 S$ and $3 S$ of the Supplementary Material. For all compounds, the instrumental detection limit was $10 \mathrm{pg}$ and the method detection limit was $100 \mathrm{ng} \mathrm{L}^{-1}$.

The mineralization of organic matter after the photo-Fenton process was evaluated by measuring the decay of dissolved organic carbon (DOC) using a TOC 5000A analyzer (Shimadzu, Kyoto, Japan). The concentrations of ferrous ions generated during the photodegradation experiments were measured using a spectrophotometric method employing 1,10-phenanthroline, with maximum absorbance at $510 \mathrm{~nm}$ [37]. The hydrogen peroxide consumption during the photo-Fenton experiments was determined by measuring the absorbance at $551 \mathrm{~nm}$ after a peroxidase-catalyzed reaction with DPD [38]. For both $\mathrm{Fe}^{2+}$ and $\mathrm{H}_{2} \mathrm{O}_{2}$ analyses, the absorbances were recorded using a UVmini-1240 spectrophotometer (Shimadzu, Kyoto, Japan).

The global degradation of the antibiotics was calculated as the average removal percentage of the four antibiotics (Eq. (3)).

Global degradation(\%)

$$
=\frac{\% \operatorname{Removal}(\mathrm{AMX})+\% \operatorname{Rem}(\mathrm{CIP})+\% \operatorname{Rem}(\mathrm{SMZ})+\% \operatorname{Rem}(\mathrm{STZ})}{4}
$$

\subsection{Quantification of bacteria}

Total coliforms and E. coli present in the RHW and AHE samples were determined according to standard methods SMEWW $229222 \mathrm{~B}$

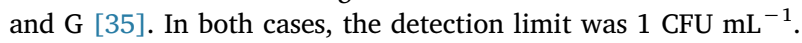




\subsection{Experimental degradation procedures}

Photo-Fenton experiments were carried out using the photoreactor shown in Fig. 1B. Two $15 \mathrm{~W}$ germicidal lamps with maximum emission at $254 \mathrm{~nm}$ were used as the radiation source. The irradiated volume of the solution was $250 \mathrm{~mL}$ and the path length was $1.5 \mathrm{~cm}$. The sample was agitated at $500 \mathrm{rpm}$ using a magnetic stirrer (model 751, Fisatom, São Paulo, Brazil). The iron citrate complex was prepared in situ by the addition of citric acid to iron nitrate solution, at a 1:1 molar ratio, resulting in a concentration of $10 \mu \mathrm{M}$ in the effluent. In the experiments performed at $\mathrm{pH} 2.5$ and 4.7, the sample $\mathrm{pH}$ was adjusted to the desired value by addition of $1 \mathrm{M} \mathrm{H}_{2} \mathrm{SO}_{4}$. An appropriate volume of $\mathrm{H}_{2} \mathrm{O}_{2}$ was then added in order to obtain a concentration of $500 \mu \mathrm{M}$ in the effluent. The initial spiked concentration of each antibiotic in the hospital effluent was $200 \mu \mathrm{g} \mathrm{L}^{-1}(0.52 \mu \mathrm{M}$ for CIP, $0.48 \mu \mathrm{M}$ for AMX, $0.79 \mu \mathrm{M}$ for STZ, and $0.72 \mu \mathrm{M}$ for SMZ).

The apparatus used for the solar photo-Fenton experiments was the same as for the photo-Fenton/UVC experiments, but with direct exposure to sunlight. The experiments were carried out in Araraquara, Brazil $\left(22^{\circ} \mathrm{S}, 48^{\circ} \mathrm{W}\right)$, during winter, under clear sky conditions between $11 \mathrm{am}$ and $2 \mathrm{pm}$. The irradiation and the accumulated solar energy dose during the experiments were measured in the UVA region (320-400 nm) using a radiometer (PMA 2100, Solar Light Co., Glenside, PA, USA), with the sensor placed at the same angle as the reactor.

\section{Results and discussion}

\subsection{Biological treatment for removal of TOC, COD, and BOD}

The physical-chemical parameters determined for characterization of the hospital wastewater are summarized in Table 1. The biological process used for the pretreatment employed an upflow anaerobic filter, with a mantle of microorganisms supported on the surfaces of green coconut shells. Removal of TOC, COD and $\mathrm{BOD}_{5}$ exceeded $90 \%$. These results showed that the anaerobic process provided efficient removal of the more labile organic matter, in agreement with the findings of Tonon et al. [34]. The removal efficiencies for turbidity and color were 90 and $57 \%$, respectively. No changes in total dissolved solids or conductivity were observed after the anaerobic process.

The total iron concentration increased from $6.3 \mu \mathrm{M}$ in the RHW to

Table 1

Main parameters determined for the raw hospital effluent (RHW) and the anaerobic hospital effluent (AHE).

\begin{tabular}{llll}
\hline Parameters & Units & RHW & AHE \\
\hline Total carbon & $\mathrm{mg} \mathrm{L}^{-1}$ & 185.9 & 94.51 \\
Inorganic carbon & $\mathrm{mg} \mathrm{L}^{-1}$ & 70.71 & 83.37 \\
Total organic carbon & $\mathrm{mg} \mathrm{L}^{-1}$ & 115.1 & 11.14 \\
$\mathrm{pH}$ & - & 7.6 & 7.4 \\
Dissolved Fe & $\mu \mathrm{M} / \mathrm{mg} \mathrm{L}^{-1}$ & $6.3 / 0.350$ & $41 / 2.29$ \\
*Dissolved Fe & $\mu \mathrm{M} / \mathrm{mg} \mathrm{L}^{-1}$ & $2.2 / 0.12$ & $4.1 / 0.230$ \\
Total nitrogen & $\mathrm{mg} \mathrm{L}^{-1}$ & 106.8 & 73 \\
PO ${ }^{3-}$ & $\mathrm{mg} \mathrm{L}^{-1}$ & 1.72 & 9.6 \\
COD & $\mathrm{mg} \mathrm{O}_{2} \mathrm{~L}^{-1}$ & 168 & 14.0 \\
BOD & $\mathrm{mg} \mathrm{O} \mathrm{L}^{-1}$ & 118 & $<\mathrm{DL}$ \\
Turbidity & $\mathrm{NTU}^{-1}$ & 79.9 & 7.87 \\
UV at 254 nm & - & 0.880 & 0.587 \\
Color & $\mathrm{mg} \mathrm{PtCo} \mathrm{L}$ & 464 & 198 \\
Odor & - & Very strong & Very strong \\
Total dissolved solids & $\mathrm{mg} \mathrm{L}^{-1}$ & 339 & 337 \\
Conductivity & $\mu \mathrm{S} \mathrm{cm}^{-1}$ & 680 & 678 \\
\hline
\end{tabular}

*Dissolved Fe without acid digestion.

DL - Detection limit.

NTU - Nephelometric turbidity unit.

COD - Chemical oxygen demand.

$\mathrm{BOD}_{5}$ - Biochemical oxygen demand.
$41 \mu \mathrm{M}$ in the AHE after the anaerobic treatment. Since the iron concentration in the AHE was much higher than in the RHW, it was also measured without acid digestion (using $\mathrm{HNO}_{3}$ and $\mathrm{H}_{2} \mathrm{O}_{2}$ ) of the sample, resulting in a 90\% lower iron concentration in the AHE $(4.1 \mu \mathrm{M})$. This indicated that iron particles derived from abrasion of the reactor were dissolved during the acid digestion and contributed to the higher concentration in the AHE. A higher $\mathrm{PO}_{4}{ }^{3-}$ concentration after the anaerobic treatment could have been due to dissolution of the phospholipid membranes of the bacteria.

\subsection{Occurrence of antibiotics in the RHW and AHE}

Various studies have reported the presence of antibiotic residues in wastewaters, typically at $\mu \mathrm{g} \mathrm{L}^{-1}$ levels, including CIP at concentrations ranging from 0.03 to $11 \mu \mathrm{g} \mathrm{L}^{-1}[36,39,40]$, AMX at $0.03 \mu \mathrm{g} \mathrm{L}^{-1}$ [36], $\mathrm{STZ}$ at $5 \times 10^{-4}-0.05 \mu \mathrm{g} \mathrm{L}^{-1}[36,41]$, SMZ at $0.005 \mu \mathrm{g} \mathrm{L}^{-1}$ [9], and SDZ at $0.029-0.38 \mu \mathrm{g} \mathrm{L}^{-1}$ [41]. In this work, the concentrations of AMX, SDZ, and CIP in the RHW were $2.5 \pm 0.4,1.3 \pm 0.1$, and $13.0 \pm 0.4 \mu \mathrm{g} \mathrm{L}^{-1}$, respectively, while SMZ and STZ were not detected in either the RHW or the AHE (Table 2). The occurrence of CIP, AMX, and SDZ at $\mu \mathrm{g} \mathrm{L}^{-1}$ levels in the RHW could be explained by the high consumption of these antibiotics in the hospital, estimated at 7.3, 26.1, and $3.0 \mathrm{~kg} \mathrm{y}^{-1}$, respectively. On the other hand, use of SMZ and STZ was much lower and the concentrations were below the detection limits.

After the anaerobic treatment, the concentration of AMX decreased to below the detection limit $\left(0.1 \mu \mathrm{g} \mathrm{L}^{-1}\right)$. However, the concentrations of CIP and SDZ were $4.5 \pm 0.1$ and $5.3 \pm 1.2 \mu \mathrm{g} \mathrm{L}^{-1}$, respectively. The results indicated that although the anaerobic process was effective for TOC, $C O D$ and $\mathrm{BOD}_{5}$ removal, antibiotics were still present at $\mu \mathrm{g} \mathrm{L}^{-1}$ levels (with the exception of AMX), showing the need for further treatment of the effluent. A substantial increase in the SDZ concentration was observed, probably due to desorption from the sludge, or variability in the amounts discharged. The inefficiency of anaerobic treatment for the removal of antibiotics has also been reported elsewhere $[42,43]$.

The differences between the concentrations of antibiotics in the inputs and outputs (removal efficiencies) of WWTPs vary according to the type of wastewater, the chemical structures and properties of the antibiotics, and the technology employed [44]. Complete removal of antibiotics is often not achieved, resulting in the discharge of these compounds into the aquatic environment. Therefore, AOPs such as the photo-Fenton process could be employed as treatments complementary to those already used in WWTP, in order to eliminate these antibiotics residues.

\subsection{Antibiotics degradation using photo-Fenton and UVC processes}

\subsubsection{Comparison of UVC, $U V C / \mathrm{H}_{2} \mathrm{O}_{2}$, and photo-Fenton/UVC processes for antibiotics degradation}

Technologies employing anaerobic reactors are attractive for the removal of organic and nitrogen loads from different types of effluents, as described in Section 3.1. However, the efficiency of removal of micro-contaminants, such as antibiotics, is questionable. In contrast,

Table 2

Concentrations of antibiotics, expressed in $\mu \mathrm{g} \mathrm{L}{ }^{-1}$, for the raw hospital wastewater (RHW) and the anaerobic hospital effluent (AHE).

\begin{tabular}{lcc}
\hline Antibiotics & Raw wastewater (RHW) & Anaerobic effluent (AHE) \\
\hline CIP & $13 \pm 0.4$ & $4.5 \pm 0.1$ \\
AMX & $2.5 \pm 0.4$ & $<\mathrm{DL}$ \\
SMZ & $<\mathrm{DL}$ & $<\mathrm{DL}$ \\
STZ & $<\mathrm{DL}$ & $<\mathrm{DL}$ \\
SDZ & $1.3 \pm 0.1$ & $5.3 \pm 1.2$ \\
\hline
\end{tabular}

DL - Detection limit. 
the high oxidizing power of the photo-Fenton process can effectively remove pharmaceutical compounds from water/wastewater systems.

FeCit was used as the iron source, since it was shown to provide more efficient degradation of CIP and fluoxetine, even at low iron concentrations, compared to free iron $\left(\mathrm{Fe}\left(\mathrm{NO}_{3}\right)_{3}\right)$ [45]. Selection of the initial FeCit and hydrogen peroxide concentrations was based on a previous study [45]. The photo-Fenton experiments were carried out at the natural $\mathrm{pH}$ of the effluent $(\approx 7.4)$, except when the effect of the initial $\mathrm{pH}$ on the degradation efficiencies was evaluated. It should be noted that the concentrations of AMX and CIP found in the anaerobic effluent were up to 10 times lower than the concentrations used in the removal experiments.

In the AHE, the background TOC concentration was approximately $10 \mathrm{mg} \mathrm{L}^{-1}$, while the sum of all the antibiotics added to the effluent (each at $200 \mu \mathrm{g} \mathrm{L}^{-1}$ ) corresponded to less than $0.4 \mathrm{mg} \mathrm{L}^{-1}$ of carbon. Therefore, it was important to determine whether the proposed processes were able to degrade these compounds present at $\mu \mathrm{L} \mathrm{L}^{-1}$ levels in a complex matrix with a much higher concentration of TOC. The TOC could be also oxidized, hence competing with the antibiotics present at very low concentrations, which could reduce the efficiency of the photo-Fenton process. Additionally, in the absence of acid digestion, the AHE had an initial iron content of $4.1 \mu \mathrm{M}\left(0.230 \mathrm{mg} \mathrm{L}^{-1}\right)$ (Table 1), probably due to corrosion of the material used to construct the anaerobic reactor.

Treatments were performed using (a) UVC lamps emitting at $254 \mathrm{~nm}$, (b) UVC/ $\mathrm{H}_{2} \mathrm{O}_{2}$ without iron addition, and (c) the photo-Fenton process (UVC/ $\mathrm{H}_{2} \mathrm{O}_{2} / \mathrm{FeCit}$ ). After $30 \mathrm{~min}$ under UVC irradiation, between 45 and $65 \%$ of the initial concentrations of the antibiotics was removed, and at the end of the experiment (after $90 \mathrm{~min}$ ), the global degradation of the antibiotics was $80 \%$ (Fig. 2A). Despite the presence of $11.14 \mathrm{mg} \mathrm{L}^{-1}$ of TOC and $83.37 \mathrm{mg} \mathrm{L}^{-1}$ of inorganic carbon (IC) at near-neutral $\mathrm{pH}$, the UVC irradiation alone provided significant degradation of the antibiotics, although no DOC removal was observed at the end of the experiment, reflecting the inability of UVC irradiation to mineralize the effluent organic matter.

Direct photolysis of organic pollutants due to electronic excitation of the molecules results in electron transfer from the excited state to the ground state of molecular oxygen [46,47], as well as homolysis to form organic radicals that also react with oxygen [48]. The presence of dissolved organic matter (DOM) can lead to the indirect degradation of organic pollutants by absorption of radiation and the consequent promotion of a photosensitive molecule to its first singlet state $\left({ }^{1} \mathrm{DOM}^{*}\right)$, where excited humic substances accelerate the degradation rate of ciprofloxacin and decrease its antimicrobial activity as reported previously [49]. The singlet excited state generally has a short lifetime, so consequently there is no significant interaction with pollutant molecules. However, the singlet state can be transformed to the longer-lived excited triplet state (Eq. (4)), which can decay to the ground state or react with $\mathrm{O}_{2}$ to form singlet oxygen $\left({ }^{1} \mathrm{O}_{2}\right)$ (Eq. (5)), a photo-oxidant that can contribute to pollutant degradation $[50,51]$.

$\mathrm{DOM}+h \nu \rightarrow{ }^{1} \mathrm{DOM}^{*} \rightarrow{ }^{3} \mathrm{DOM}^{*}$

${ }^{3} \mathrm{DOM}^{*}+\mathrm{O}_{2} \rightarrow \mathrm{DOM}+{ }^{1} \mathrm{O}_{2}$

The effect of hydrogen peroxide photolysis was also evaluated, with the pseudo-first order rate constants for degradation of the antibiotics mixture ranging from 0.035 to $0.063 \mathrm{~min}^{-1}$ (Table 3). Total degradation of AMX and STZ was achieved after $60 \mathrm{~min}$, while over $80 \%$ degradation of CIP and SMZ was observed during the same time (Fig. 2B). The higher rate of antibiotics degradation achieved using $\mathrm{UVC} / \mathrm{H}_{2} \mathrm{O}_{2}$, compared to irradiation with a germicidal lamp (254 nm wavelength emission) alone, was due to the photolysis of hydrogen peroxide to produce two hydroxyl radicals [48]. However, the absolute contribution of the UVC $/ \mathrm{H}_{2} \mathrm{O}_{2}$ process could not be measured, because the AHE contained $4.1 \mu \mathrm{M}$ of soluble iron, which could have contributed to hydrogen peroxide decomposition by means of the Fenton reaction.

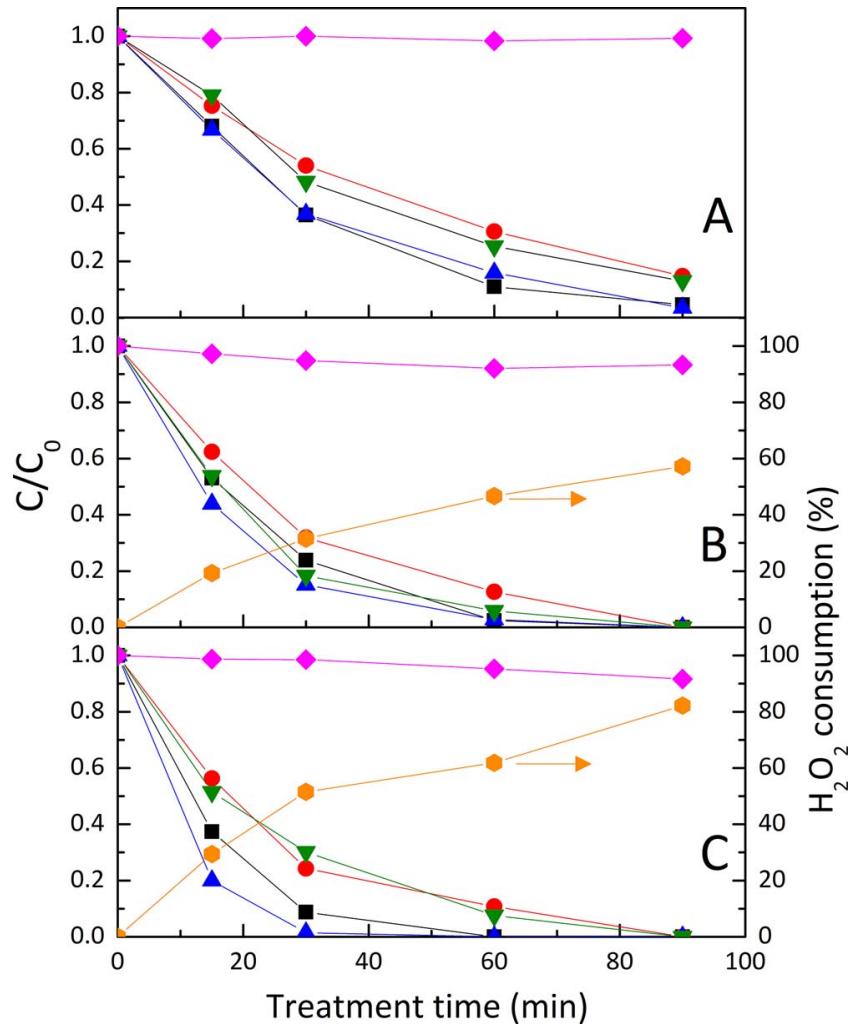

Fig. 2. Comparison of the UVC (A), UVC/ $\mathrm{H}_{2} \mathrm{O}_{2}$ (B), and $\mathrm{UVC} / \mathrm{H}_{2} \mathrm{O}_{2} / \mathrm{FeCit}$ (C) processes for degradation of the antibiotics mixture in the AHE. Experimental conditions: $\left[\mathrm{H}_{2} \mathrm{O}_{2}\right]$ $=500 \mu \mathrm{M} ; \quad[\mathrm{FeCit}]=10 \mu \mathrm{M} ; \quad \mathrm{pH}_{\text {initial }}=7.4 ; \quad \mathrm{TOC}_{\text {initial }}=10.1 \mathrm{mg} \mathrm{L}^{-1}$; $\mathrm{IC}_{\text {initial }}=74.5 \mathrm{mg} \mathrm{L}^{-1} ;[\mathrm{AMX}]=[\mathrm{CIP}]=[\mathrm{STZ}]=[\mathrm{SMZ}]=200 \mu \mathrm{g} \mathrm{L}^{-1}$. Symbols: $(\square$

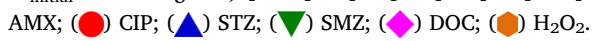

Although degradation of the antibiotics to levels below the detection limits was achieved after $90 \mathrm{~min}$, only $7 \%$ of the DOC was removed and $60 \%$ of the $\mathrm{H}_{2} \mathrm{O}_{2}$ was consumed at the end of the experiment.

The efficiency of the photo-Fenton process for degradation of the pharmaceuticals was also evaluated using UVC lamp irradiation and the results were compared with those obtained for the UVC/ $\mathrm{H}_{2} \mathrm{O}_{2}$ and UVC processes. Photo-Fenton degradation is usually carried out in acid media. However, in the present work, the experiments could be conducted at the natural $\mathrm{pH}$ of the effluent $(\mathrm{pH} \approx 7.4)$, due to the low iron concentration and the use of citrate, which acts as a polydentate ligand and complexes iron, hence keeping it soluble. This has the advantage of avoiding the need for acidification/neutralization of wastewater, which could be unfeasible in large-scale applications. Furthermore, citrate presents higher molar absorption coefficients in the UV-vis region, compared to iron aqua complexes, producing $\mathrm{Fe}^{2+}$ via ligand-to-metal charge transfer [25].

The photo-Fenton process in the presence of citrate was able to degrade the antibiotics to levels below the detection limit after $30 \mathrm{~min}$ (STZ), $60 \mathrm{~min}$ (AMX), and $90 \mathrm{~min}$ (CIP and SMZ) (Fig. 2C). The addition of iron to the effluent improved the degradation, as can be seen by the higher $k_{o b s}$ values, compared to the UVC/ $\mathrm{H}_{2} \mathrm{O}_{2}$ system, with the greatest increase in $k_{\text {obs }}$ (2.33-fold) being obtained for STZ (Table 3). The global degradation of the antibiotics after treatment for $30 \mathrm{~min}$ increased from $57 \%$ for the UVC system to $79 \%$ with the addition of $\mathrm{H}_{2} \mathrm{O}_{2}$ and $83 \%$ with the addition of $\mathrm{H}_{2} \mathrm{O}_{2}$ and $\mathrm{FeCit}$. It is noteworthy that very similar degradations were obtained for the UVC/ $\mathrm{H}_{2} \mathrm{O}_{2}$ and $\mathrm{UVC} / \mathrm{H}_{2} \mathrm{O}_{2} / \mathrm{FeCit}$ systems, due to the presence of iron in both cases.

The generation of $\mathrm{Fe}^{2+}$ in the presence of FeCit was very fast, reaching about $12.5 \mu \mathrm{M}$ within $15 \mathrm{~min}$ of irradiation and decreasing to less than $2 \mu \mathrm{M}$ after $90 \mathrm{~min}$ following reaction with $\mathrm{H}_{2} \mathrm{O}_{2}$ (Fig. 3A). The oxidation of $\mathrm{Fe}^{2+}$ was accompanied by citrate degradation, as reported 
Table 3

Kinetic parameters obtained for degradation of the antibiotics under different experimental conditions.

\begin{tabular}{|c|c|c|c|c|c|c|c|c|}
\hline Matrix & $\mathrm{pH}$ & FeCit $(\mu \mathrm{M})$ & $\mathrm{H}_{2} \mathrm{O}_{2}(\mu \mathrm{M})$ & Light source & $\mathrm{k}_{\mathrm{AMX}}\left(\min ^{-1}\right)$ & $\mathrm{k}_{\mathrm{CIP}}\left(\min ^{-1}\right)$ & $\mathrm{k}_{\mathrm{STZ}}\left(\min ^{-1}\right)$ & $\mathrm{k}_{\mathrm{SMZ}}\left(\min ^{-1}\right)$ \\
\hline AHE & 7.4 & - & - & UVC & 0.036 & 0.021 & 0.037 & 0.023 \\
\hline AHE & 7.4 & - & 500 & UVC & 0.063 & 0.035 & 0.060 & 0.048 \\
\hline AHE & 7.4 & 10 & 500 & UVC & 0.081 & 0.038 & 0.14 & 0.043 \\
\hline AHE & 4.7 & 10 & 500 & UVC & 0.22 & 0.091 & 0.17 & 0.087 \\
\hline AHE & 2.5 & 10 & 500 & UVC & 0.29 & 0.12 & 0.27 & 0.11 \\
\hline AHE & 7.4 & 10 & 500 & UVA & 0.018 & 0.019 & 0.0033 & 0.0024 \\
\hline AHE & 7.4 & 10 & 500 & Solar & 0.017 & 0.018 & 0.011 & 0.0065 \\
\hline RHW & 7.6 & 10 & 500 & UVC & 0.054 & 0.039 & 0.075 & 0.033 \\
\hline
\end{tabular}

AHE - anaerobic hospital effluent.

RHW - raw hospital wastewater.

in previous work [45]. A decrease of the citrate concentration leads to iron precipitation, strongly harming the photoreduction and decreasing the rate of degradation of target compounds. The complete consumption of $500 \mu \mathrm{M} \mathrm{H}_{2} \mathrm{O}_{2}$ was observed after 90 min of reaction.

The Fenton reaction is strongly dependent on the iron and hydrogen peroxide concentrations, and in the absence of these reagents, the reaction rate decreases to a minimum. Therefore, an experiment was performed with a second addition of $500 \mu \mathrm{M} \mathrm{H}_{2} \mathrm{O}_{2}$ and $10 \mu \mathrm{M}$ FeCit at $60 \mathrm{~min}$, in order to increase the removal of DOC. This resulted in $18 \%$ DOC removal after $120 \mathrm{~min}$ (Fig. 3B), equivalent to a two-fold higher mineralization, compared to the single addition of Fenton reagents.

\subsubsection{Influence of $p H$ on antibiotics degradation}

The photo-Fenton/UVC process was evaluated at $\mathrm{pH} 2.5,4.7$, and 7.4. A lower efficiency at high $\mathrm{pH}$ values is related to the formation and precipitation of iron hydroxide, which affects the degradation process.

At $\mathrm{pH} 2.5$, the global degradation of the antibiotics reached $100 \%$ after only $30 \mathrm{~min}$ of treatment, with $k_{\text {obs }}$ increasing in the order 0.11 (SMZ), 0.12 (CIP), 0.27 (STZ), and $0.29 \mathrm{~min}^{-1}$ (AMX) (Table 3). The DOC removal was $38 \%$, and the $\mathrm{H}_{2} \mathrm{O}_{2}$ was completely consumed in $90 \mathrm{~min}$ (Fig. 4A). In this case, acidification of the sample before the

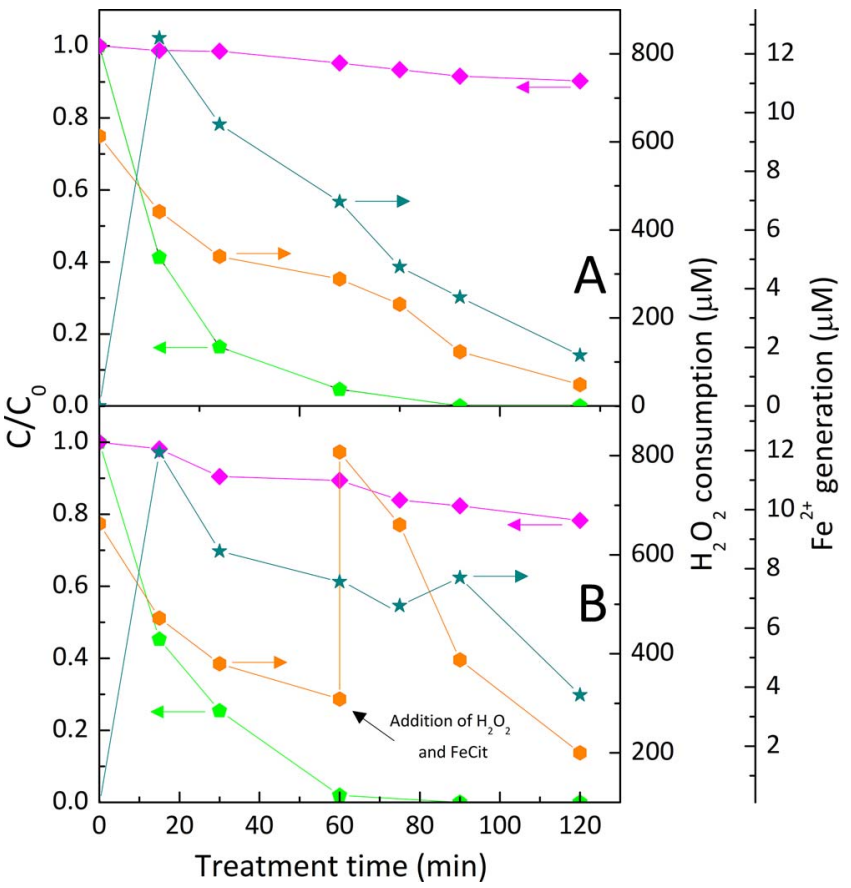

Fig. 3. Influence of single (A) and double (B) addition of $\mathrm{H}_{2} \mathrm{O}_{2}$ and FeCit on degradation of the antibiotics mixture in the AHE by the photo-Fenton process. Experimental conditions: $\quad\left[\mathrm{H}_{2} \mathrm{O}_{2}\right]=500 \mu \mathrm{M} ; \quad[\mathrm{FeCit}]=10 \mu \mathrm{M} ; \quad[\mathrm{AMX}]=[\mathrm{CIP}]=[\mathrm{STZ}]=[$ SMZ $]$ $=200 \mu \mathrm{g} \mathrm{L}^{-1} ; \mathrm{pH}_{\text {initial }}=7.4$; TOC $_{\text {initial }}=10.1 \mathrm{mg} \mathrm{L}^{-1} ; \mathrm{IC}_{\text {initial }}=74.5 \mathrm{mg} \mathrm{L}^{-1}$. Symbols: ( $\Sigma$ antibiotics; $(\circlearrowleft)$ DOC; $(\Delta) \mathrm{Fe}^{2+} ;(\circlearrowleft) \mathrm{H}_{2} \mathrm{O}_{2}$. start of the experiments removed most of the carbonate/bicarbonate present in the effluent $\left(83.37 \mathrm{mg} \mathrm{L}^{-1}\right)$, which would otherwise have scavenged the hydroxyl radicals formed. The acidified sample required stirring for $30 \mathrm{~min}$ in order to decrease the carbonate concentration to $2.5 \mathrm{mg} \mathrm{L}^{-1}$ IC.

At $\mathrm{pH} 4.7$, the initial IC concentration was $8.2 \mathrm{mg} \mathrm{L}^{-1}$, while the TOC concentration remained almost constant. The global removal of the antibiotics was $85 \%$ after $30 \mathrm{~min}$, with $k_{\text {obs }}$ values ranging from 0.087 to $0.22 \mathrm{~min}^{-1}$ for the different compounds (Table 3). The DOC removal was $25 \%$ at $90 \mathrm{~min}$, with $94 \%$ consumption of the hydrogen peroxide (Fig. 4B). At the natural $\mathrm{pH}$, the global degradation of the antibiotics after $30 \mathrm{~min}$ was slightly lower than at $\mathrm{pH} 2.5$, with $8.5 \%$ removal of DOC (Fig. 4C). Overall, it could be seen that the decrease of $\mathrm{pH}$ from 7.4 to 4.7 and to 2.5 resulted in higher rates of degradation of the antibiotics, as well as greater mineralization.

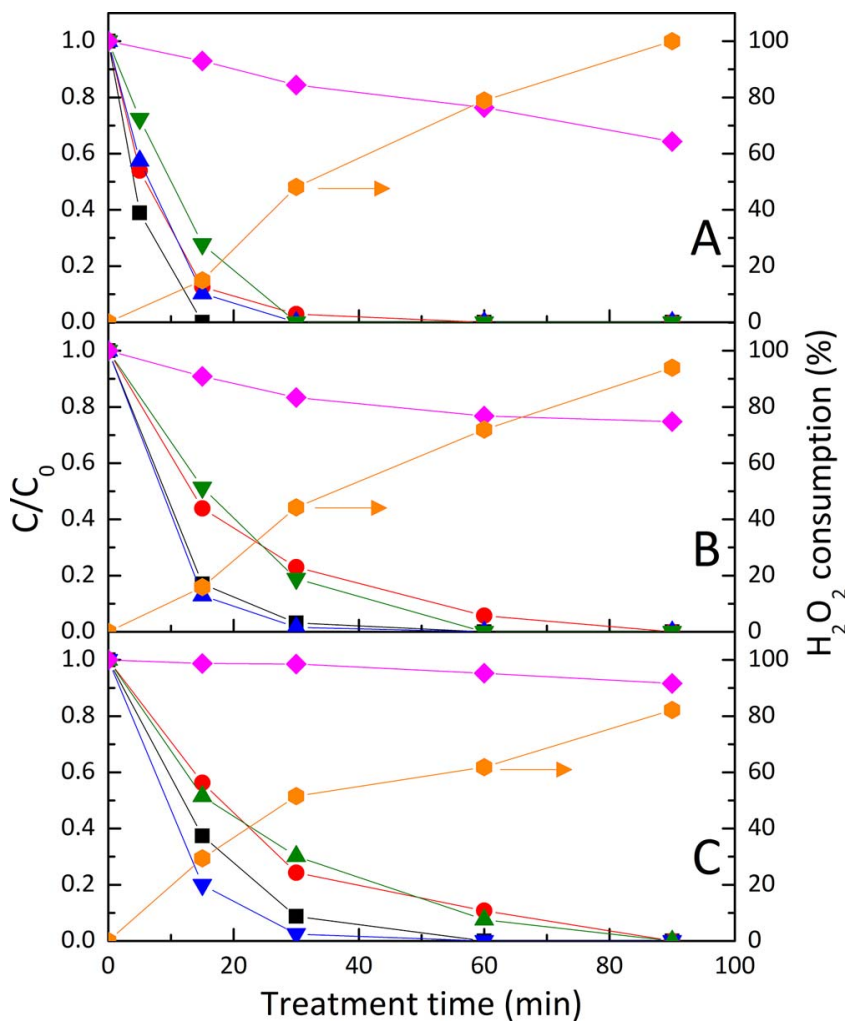

Fig. 4. Effect of $\mathrm{pH}$ on degradation of the antibiotics mixture in the AHE by the photoFenton process. Experimental conditions: $\left[\mathrm{H}_{2} \mathrm{O}_{2}\right]=500 \mu \mathrm{M}$; $[\mathrm{FeCit}]=10 \mu \mathrm{M} ;[\mathrm{AMX}]=$ $[\mathrm{CIP}]=[\mathrm{STZ}]=[\mathrm{SMZ}]=200 \mu \mathrm{L}^{-1} . \quad$ (A) $\mathrm{pH}_{\text {initial }}=2.5 ; \quad \mathrm{TOC}_{\text {initial }}=8.6 \mathrm{mg} \mathrm{L}^{-1}$; $\mathrm{IC}_{\text {initial }}=2.5 \mathrm{mg} \mathrm{L}^{-1}$. (B) $\mathrm{pH}_{\text {initial }}=4.7$; $\mathrm{TOC}_{\text {initial }}=8.3 \mathrm{mg} \mathrm{L}^{-1} ; \mathrm{IC}_{\text {initial }}=8.2 \mathrm{mg} \mathrm{L}^{-1}$. (C) $\mathrm{pH}_{\text {initial }}=7.4$; $\mathrm{TOC}_{\text {initial }}=10.1 \mathrm{mg} \mathrm{L}^{-1}$; $\mathrm{IC}_{\text {initial }}=74.5 \mathrm{mg} \mathrm{L}^{-1}$. Symbols: (更) AMX;

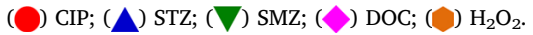




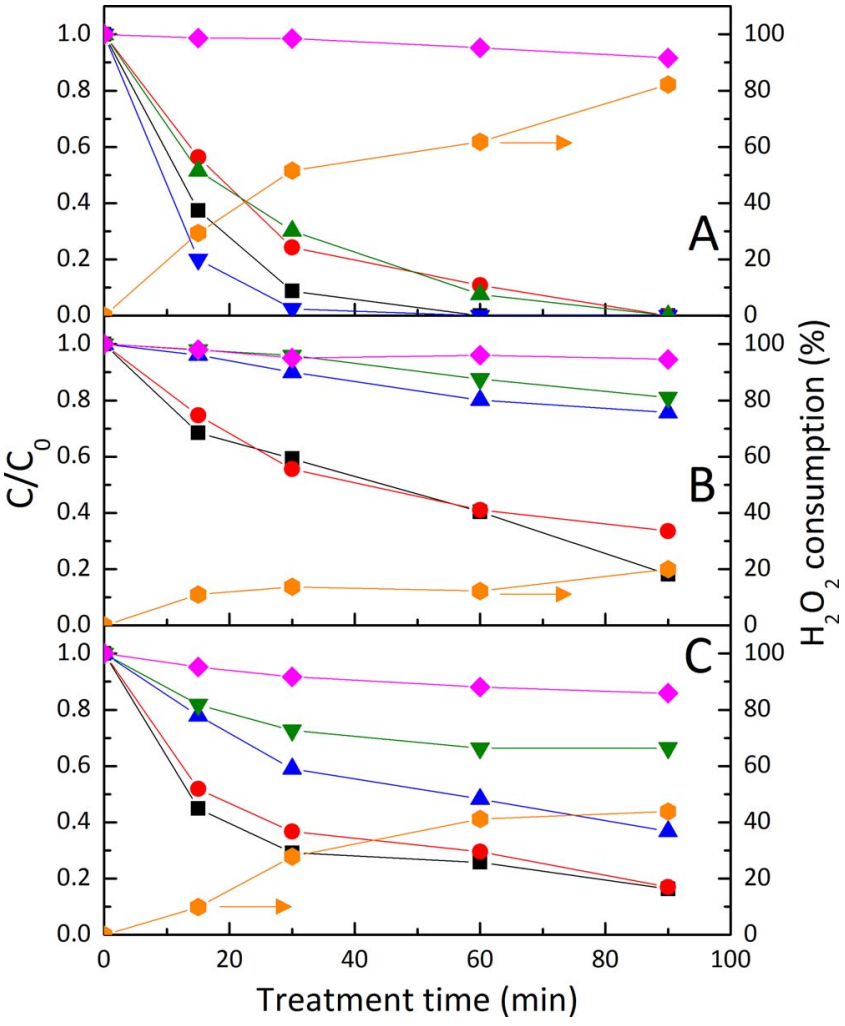

Fig. 5. Comparison of photo-Fenton processes using UVC lamp (A), UVA lamp (B), and sunlight irradiation (C) for degradation of the antibiotics mixture in the AHE. Experimental conditions: $\quad\left[\mathrm{H}_{2} \mathrm{O}_{2}\right]=500 \mu \mathrm{M} ; \quad[\mathrm{FeCit}]=10 \mu \mathrm{M} ; \quad[\mathrm{AMX}]=[\mathrm{CIP}]=[\mathrm{STZ}]=[\mathrm{SMZ}]$ $=200 \mu \mathrm{g} \mathrm{L}^{-1} ; \mathrm{pH}_{\text {initial }}=7.4 ; \mathrm{TOC}_{\text {initial }}=10.1 \mathrm{mg} \mathrm{L}^{-1} ; \mathrm{IC}_{\text {initial }}=74.5 \mathrm{mg} \mathrm{L}^{-1}$. Symbols:

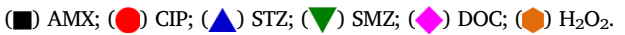

\subsubsection{Effect of irradiation source on antibiotics degradation}

Iron complexes absorb in the near UV and up to $450 \mathrm{~nm}$, suggesting that solar irradiation could be used to promote the degradation of the antibiotics, hence reducing the cost of irradiation. Therefore, the efficiency of degradation of the antibiotics at the natural $\mathrm{pH}$ of the effluent (AHE) was compared using three sources of radiation: UVC lamp, UVA lamp, and solar.

Use of the UVC/ $\mathrm{H}_{2} \mathrm{O}_{2} / \mathrm{FeCit}$ system resulted in total degradation of the antibiotics and $8.5 \%$ mineralization after $90 \mathrm{~min}$, with $82 \%$ consumption of the hydrogen peroxide (Fig. 5A). Under these conditions, there were synergistic effects among the photo-Fenton reaction, $\mathrm{H}_{2} \mathrm{O}_{2}$ photolysis, and photolysis of the antibiotics. The germicidal lamp with maximum emission at $254 \mathrm{~nm}$ could photolyze both hydrogen peroxide and the target compounds, as well as photochemically reduce $\mathrm{Fe}^{3+}$ to $\mathrm{Fe}^{2+}$, hence enhancing the Fenton reaction. In control experiments at $\mathrm{pH} 7.4$, using only hydrogen peroxide or FeCit, in the absence of UVC light, no degradation of the antibiotics was observed after $60 \mathrm{~min}$.

Using the black light lamp as the radiation source, with maximum emission at $365 \mathrm{~nm}$, global degradation of the antibiotics at the end of the experiment was only $47 \%$, much lower than the value obtained with the germicidal lamp (100\%). The DOC removal was $4.5 \%$ and only $20 \%$ of the $\mathrm{H}_{2} \mathrm{O}_{2}$ was consumed after 90 min (Fig. 5B). The calculated kinetic parameters (Table 3 ) indicated that degradation of the sulfonamide antibiotics (STZ and SMZ) was severely restricted when the black light lamp was used, with rate constants of 0.0033 and $0.0024 \mathrm{~min}^{-1}$, respectively. These values were approximately 40 and 20 times lower than the $k_{o b s}$ values of 0.14 and $0.043 \mathrm{~min}^{-1}$ obtained using the germicidal lamp.

Under solar irradiation, global antibiotics degradation of $66 \%$ was obtained after $90 \mathrm{~min}$, with $43 \%$ consumption of $\mathrm{H}_{2} \mathrm{O}_{2}$ and $11 \% \mathrm{mi}-$ neralization (Fig. 5C). Higher degradation of the antibiotics was observed under sunlight than under the black light lamp. In this case, the sunlight UVA energy dose during treatment for $90 \mathrm{~min}$ was $14.1 \mathrm{~J} \mathrm{~cm}^{-2}$, while the energy dose provided by the black light lamp was only $4.62 \mathrm{~J} \mathrm{~cm}^{-2}$, approximately three times lower. Solar radiation has a much broader spectral range than the radiation from black light lamps, resulting in greater photoreduction of Fe(III) following absorption of the radiation by the $\mathrm{Fe}(\mathrm{III})$-citrate complex. Although the predominant FeCit species at $\mathrm{pH} 4-6\left(\mathrm{Fe}(\mathrm{OH})(\mathrm{Cit})^{-}\right)$shows lower photoactivity (with a quantum yield of $\mathrm{Fe}(\mathrm{II})$ of $0.28-0.21$ at $436 \mathrm{~nm}$ $[25,52])$, the values are higher than those observed with iron aqua complexes.

The UVC radiation provided the best degradation of the antibiotics, since it played an important role in various individual processes, resulting in greater overall efficiency. However, despite the lower efficiency of the solar process, the possibility of saving energy costs is an important advantage. Despite the inherent variability of solar radiation, the results indicated that it could be effective for removal of antibiotics from hospital effluents using the photo-Fenton process.

\subsubsection{Effect of the matrix on antibiotics degradation}

Evaluation was made of the photodegradation of the antibiotics present in the AHE and RHW media. These effluents differ considerably, especially in terms of TOC, IC, and BOD, so comparison of the degradation behaviors could provide information concerning the influence of these parameters. Both $\mathrm{CO}_{3}{ }^{2-} / \mathrm{HCO}_{3}{ }^{-}$and organic carbon can hinder the efficiency of the process, due to $\cdot \mathrm{OH}$ scavenging in side reactions, hence decreasing the process efficiency.

The AHE contained $94.51 \mathrm{mg} \mathrm{L}^{-1}$ of TC, of which $83.37 \mathrm{mg} \mathrm{L}^{-1}$ was IC, and $14.0 \mathrm{mg} \mathrm{L}^{-1} \mathrm{COD}$. The RHW showed higher TC of $185.9 \mathrm{mg} \mathrm{L}^{-1}$, with $70.71 \mathrm{mg} \mathrm{L}^{-1}$ of IC, and $168 \mathrm{mg} \mathrm{L}^{-1}$ COD. No adjustment of $\mathrm{pH}$ was applied, with the experiments being performed at the natural $\mathrm{pH}$ values of 7.4 (AHE) and 7.6 (RHW).

Global degradation of the antibiotics in the AHE reached $83 \%$ in $30 \mathrm{~min}$, with removal of approximately $1 \mathrm{mg}$ of TOC (corresponding to $8.5 \%$ mineralization of AHE) and $82 \%$ hydrogen peroxide consumption at the end of the experiment (Fig. 6A). The initial rate constants, in ascending order, were $0.038,0.043,0.081$, and $0.14 \mathrm{~min}^{-1}$ for CIP, SMZ, AMX, and STZ, respectively (Table 3). The $\mathrm{H}_{2} \mathrm{O}_{2}$ concentration used was approximately 5 times higher than the stoichiometric amount $(111 \mu \mathrm{M})$ required for total degradation of $2.5 \mu \mathrm{M}$ of the antibiotics $\left(4 \times 200 \mu \mathrm{L} \mathrm{L}^{-1}\right)$ to $\mathrm{CO}_{2}$, water, and inorganic ions. Although the stoichiometric amount of hydrogen peroxide necessary for complete oxidation of the organic matter in the AHE was $8.75 \mathrm{mM}$, a much lower $\mathrm{H}_{2} \mathrm{O}_{2}$ concentration was used, since the main goal of the tertiary photoFenton treatment proposed in this work was the degradation of antibiotics present at very low concentrations, rather than total mineralization of the effluent.

Despite the greater complexity of the RHW, compared to the AHE, the rate constants for degradation of the antibiotics were very similar for CIP and SMZ, while the value decreased by $50 \%$ in the case of STZ (Table 3). The initial rate constants, in ascending order, were 0.033 , $0.039,0.054$, and $0.075 \mathrm{~min}^{-1}$ for SMZ, CIP, AMX, and STZ, respectively. The global degradation achieved after $30 \mathrm{~min}$ was $74 \%$, with $66 \%$ consumption of $\mathrm{H}_{2} \mathrm{O}_{2}$ and $16 \%$ mineralization at the end of the experiment.

It is possible that the presence of nitrate may have increased the degradation rates of the contaminants, due to the formation of $\mathrm{OH}$ radicals by nitrate photolysis. This effect was observed previously using irradiation at wavelengths shorter than $280 \mathrm{~nm}$ [53], as in the case of the germicidal lamp employed in this work. It has also been found that the presence of DOM can accelerate the degradation of contaminants by the formation of oxidizing species such as singlet oxygen, $\mathrm{H}_{2} \mathrm{O}_{2}$, and $\mathrm{OH}$ [54].

In addition, adsorption onto particulate matter has been reported for some classes of antibiotics, including tetracyclines, sulfonamides, and fluoroquinolones [55]. Aristilde and Sposito [56] observed 


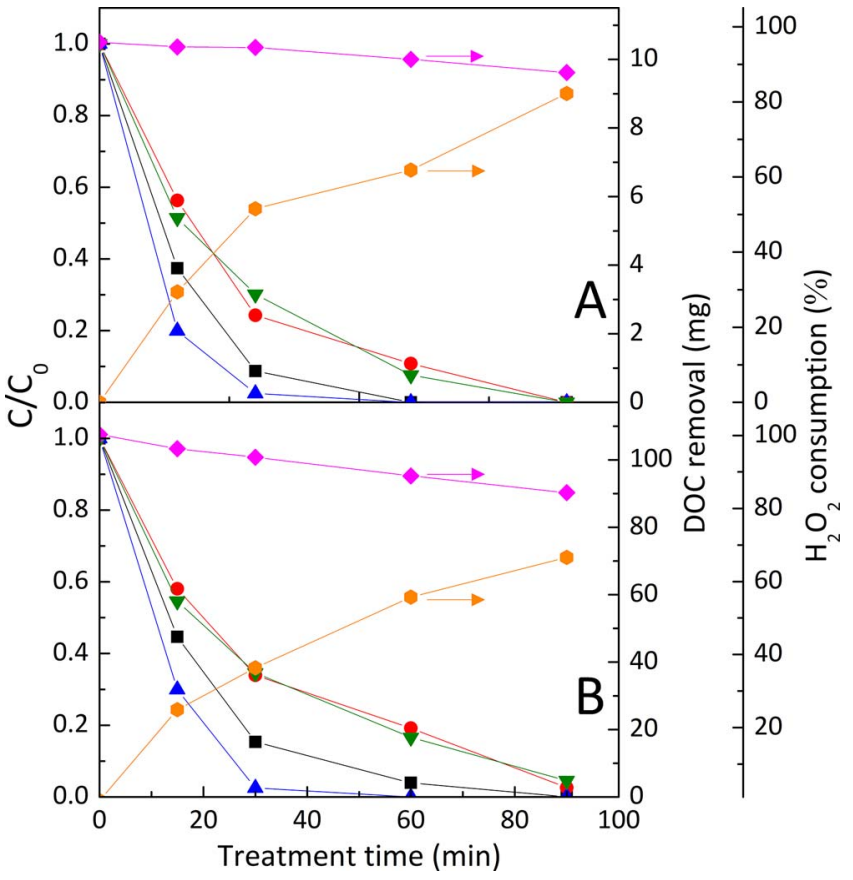

Fig. 6. Influence of the matrix on degradation of the antibiotics mixture in the AHE (A) and RHW (B) using the photo-Fenton process. Experimental conditions: $\left[\mathrm{H}_{2} \mathrm{O}_{2}\right]$ $=500 \mu \mathrm{M} ; \quad[\mathrm{FeCit}]=10 \mu \mathrm{M} ; \quad[\mathrm{AMX}]=[\mathrm{CIP}]=[\mathrm{STZ}]=[\mathrm{SMZ}]=200 \mu \mathrm{g} \mathrm{L}^{-1} . \quad$ (A) $\mathrm{pH}_{\text {initial }}=7.4 ; \quad \mathrm{TOC}_{\text {initial }}=10.1 \mathrm{mg} \mathrm{L}^{-1} ; \quad \mathrm{IC}_{\text {initial }}=74.5 \mathrm{mg} \mathrm{L}^{-1} . \quad$ (B) $\mathrm{pH}_{\text {initial }}=7.6$; $\mathrm{TOC}_{\text {initial }}=105.1 \mathrm{mg} \mathrm{L}^{-1} ; \mathrm{IC}_{\text {initial }}=64.6 \mathrm{mg} \mathrm{L}^{-1}$. Symbols: $(\square) \mathrm{AMX} ;(\bigcirc) \mathrm{CIP} ;($ STZ; ( $)$ SMZ; ( ) DOC; $(\bigcirc) \mathrm{H}_{2} \mathrm{O}_{2}$.

complexation of the zwitterionic form of CIP in protonated humic substances. Given that antibiotics of the fluoroquinolone class (such as CIP) have sorption coefficients $\left(\mathrm{k}_{d}\right)$ ranging from 70 to $353,000 \mathrm{~kg} \mathrm{~L}^{-1}$, the sorption of CIP onto solid matrices could be the primary mechanism for its removal from effluent $[57,58]$, since the concentration of total dissolved solids was in the region of $340 \mathrm{mg} \mathrm{L}^{-1}$ (Table 1).

However, the concentrations of the spiked antibiotics in RHW did not alter significantly after stirring in the dark for $1 \mathrm{~h}$, indicating that sorption/complexation of the antibiotics involving the constituents of this matrix did not occur and that the main removal mechanisms were oxidation by photogenerated $\cdot \mathrm{OH}$ and photolysis during irradiation.

The chromatograms obtained for the RHW and AHE before the photo-Fenton treatment revealed the presence of several compounds with high intensity peaks, especially for the AHE, with retention times of 6.6, 7.3, and $16.9 \mathrm{~min}$, while the RHW chromatogram showed major peaks at retention times of 15.2, 15.9, and $16.8 \mathrm{~min}$ (Fig. 7A). After application of the photo-Fenton process to the AHE, resulting in treated hospital effluent (THE), the aforementioned peaks disappeared and a new peak appeared at $17.9 \mathrm{~min}$, possibly due to a degradation product of contaminants present in the effluent.

The UV-vis spectra of the RHW, AHE, and THE samples (inset of Fig. 7A) showed a slight decrease of absorbance after the anaerobic treatment and the photo-Fenton/UVC process, indicating the degradation of absorbing organic matter.

The chromatogram for the spiked AHE (using $200 \mu \mathrm{g} \mathrm{L}^{-1}$ of each antibiotic and 10-fold preconcentration) showed peaks at 5.0, 13.8, 15.7, and $18.3 \mathrm{~min}$, corresponding to AMX, STZ, CIP, and SMZ, respectively, together with other peaks for compounds already present in the effluent. After $15 \mathrm{~min}$ of photo-Fenton treatment, the intensities of the antibiotic peaks showed sharp decreases, while no antibiotics were detected after $90 \mathrm{~min}$, indicating their oxidation to levels below the detection limit (Fig. 7B). Carboxylic acids including citric, succinic, and acetic acids were identified in the AHE (data not shown), which were also degraded to levels below the detection limit during the photoFenton process. These acids present in the AHE were formed during the

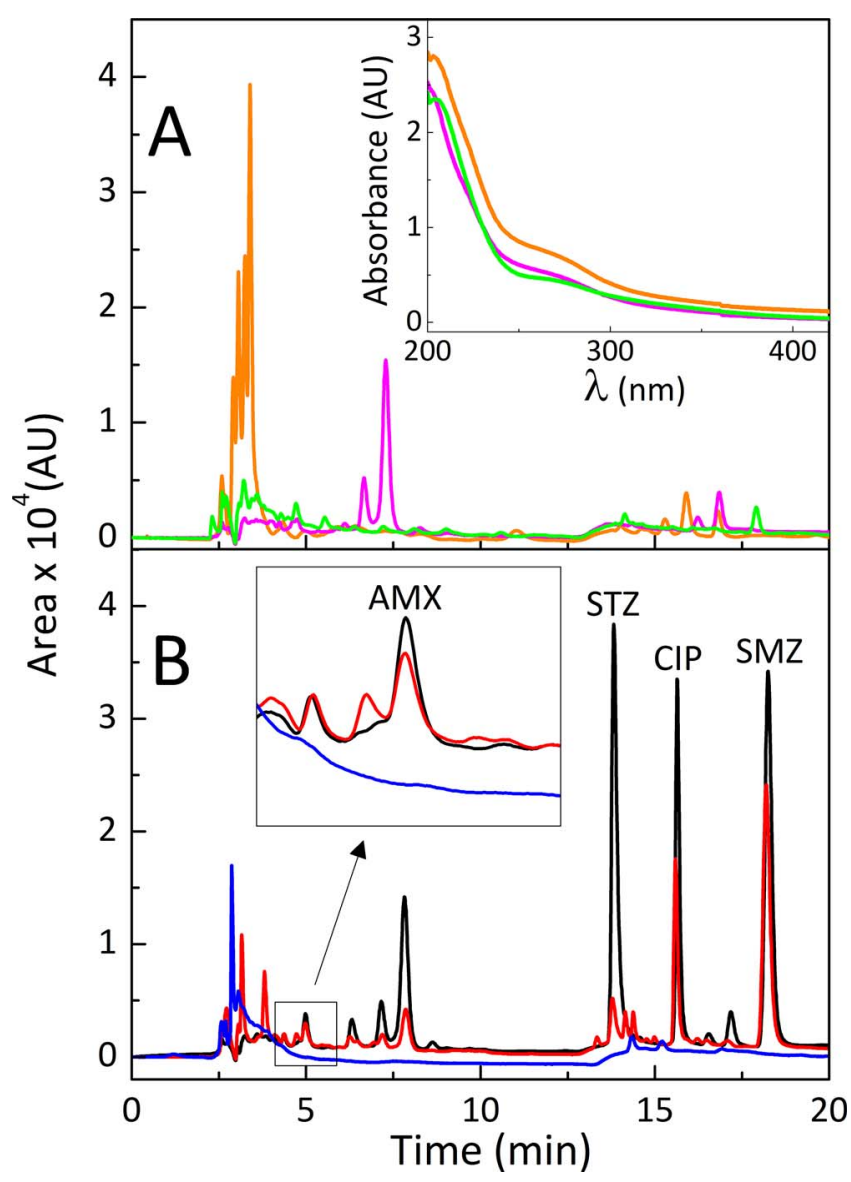

Fig. 7. Chromatograms obtained for the RHW, AHE, and THE (A). Chromatograms for the AHE fortified with antibiotics during the photo-Fenton process $(\lambda=254 \mathrm{~nm})$ (B). Insert: UV spectra of the RHW, AHE, and THE. Experimental conditions: $\left[\mathrm{H}_{2} \mathrm{O}_{2}\right]=500 \mu \mathrm{M}$; $[$ FeCit $]=10 \mu \mathrm{M} ;[$ AMX $]=[\mathrm{CIP}]=[\mathrm{STZ}]=[\mathrm{SMZ}]=200 \mu \mathrm{g} \mathrm{L}^{-1}$. Symbols: $(\mathrm{A})(-)$ RHW; (—) AHE; (—) THE. (B) (-) $0 \mathrm{~min}$; (-) $15 \mathrm{~min}$; (-) $90 \mathrm{~min}$.

biological treatment process applied to the RHW. In the particular case of succinic acid, succinate could be released because it is a counter ion used in certain pharmaceuticals in order to increase their solubility in water.

After 90 min of photo-Fenton/UVC treatment, the RHW and AHE both became more translucent (Fig. 1S), with significant reductions of their strong odors, hence improving the quality of the final effluent to be discharged.

\subsection{Disinfection of anaerobic hospital effluent by the photo-Fenton/UVC process}

In addition to the antibiotics content of hospital effluents, another important hazard concerns the presence of pathogens. Therefore, it is important to employ a treatment process able to efficiently remove both antibiotics and pathogens. The quantification of total coliforms and $E$. coli in the RHW revealed the presence of $2.6 \times 10^{8}$ and $7.0 \times 10^{6}$ colony-forming units per $100 \mathrm{~mL}(\mathrm{CFU} / 100 \mathrm{~mL})$, respectively. The AHE showed slightly lower values of $3.8 \times 10^{7}$ and $2.5 \times 10^{5} \mathrm{CFU} / 100 \mathrm{~mL}$ for total coliforms and E. coli, respectively, confirming the inefficiency of anaerobic treatment for the disinfection of hospital effluent (Fig. 8A).

The photo-Fenton treatment decreased the bacterial concentration of the E. coli and total coliforms (Fig. 8B). The photo-Fenton process assisted by UVA irradiation caused only slight reductions of total coliforms and E. coli, of 1-log and 0.4-log, respectively, in the AHE after $90 \mathrm{~min}$ of treatment. Considerably higher disinfection of the bacteria was obtained under solar irradiation $\left(14.1 \mathrm{~J} \mathrm{~cm}^{-2}\right.$ energy dose), with 3.7-log and 2.4-log reductions achieved for total coliforms and E. coli, 

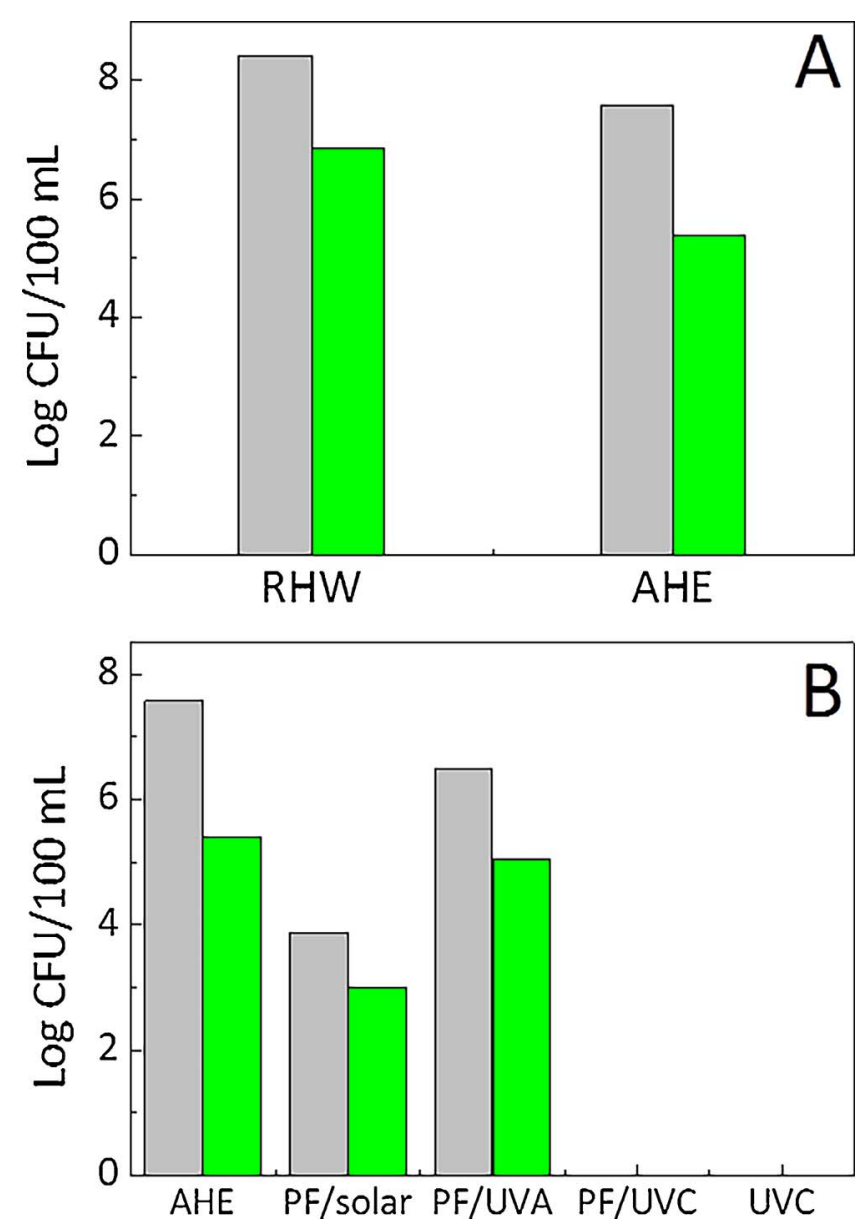

Fig. 8. Counts of bacteria present in the RHW and AHE (A). Inactivation of bacteria present in the AHE after UVC and photo-Fenton (UVC, UVA, and solar) processes (B). Experimental conditions: $\left[\mathrm{H}_{2} \mathrm{O}_{2}\right]=500 \mu \mathrm{M}$; $[\mathrm{FeCit}]=10 \mu \mathrm{M} ; \mathrm{pH}_{\text {initial }}=7.4$; treatment time $=90$ min. Symbols: $(\quad)$ total coliforms; ( $)$ E. coli.

respectively. However, as already mentioned, the accumulated energy dose provided by the UVA lamp was lower $\left(4.62 \mathrm{~J} \mathrm{~cm}^{-2}\right.$ ), which contributed to the lower bacterial disinfection. The $\cdot \mathrm{OH}$ formed in the photo-Fenton reaction can induce reactions involving lipids, proteins, and DNA, causing lethal effects in bacteria [59,60]. In addition, the bacterial disinfection during photo-Fenton treatment can be caused by the diffusion of $\mathrm{Fe}^{2+}$ into the cells, where $\cdot \mathrm{OH}$ can then be produced during internal Fenton reactions [61].

Irradiation with UVC alone or in the presence of FeCit $(10 \mu \mathrm{M})$ and hydrogen peroxide $(500 \mu \mathrm{M})$ resulted in the quantitative disinfection of total coliforms and $E$. coli present in the AHE to levels below the quantification limits after $90 \mathrm{~min}$ (Fig. 8B). The exposure of bacteria to UVC radiation results in damage to the nucleic acids, causing inactivation [62].

A previous study reported the incomplete inactivation of total coliforms present in a sewage treatment plant effluent, using a solar photo-Fenton system at natural $\mathrm{pH}$, with $0.2 \mathrm{mM}$ of iron and $1.5 \mathrm{mM}$ of $\mathrm{H}_{2} \mathrm{O}_{2}$ [63]. Elsewhere, total disinfection of $E$. coli in Milli-Q water was obtained using a solar photo-Fenton system with concentrations of additives $\left(10.7 \mu \mathrm{M} \mathrm{Fe} e^{2+/ 3+}\right.$ and $\left.300 \mu \mathrm{M} \mathrm{H}_{2} \mathrm{O}_{2}\right)$ similar to those employed in the present work [59]. The disinfection efficiency of UVC is highly dependent on the type of matrix. In the present case, the proposed system (UVC/ $\mathrm{H}_{2} \mathrm{O}_{2} / \mathrm{FeCit}$ ) was effective for the disinfection of total coliforms and $E$. coli in the effluent matrices evaluated.

\section{Conclusions}

UVC-assisted photo-Fenton treatment of anaerobic hospital effluent spiked with four antibiotics at $\mu \mathrm{g} \mathrm{L}^{-1}$ levels was successfully applied at near-neutral $\mathrm{pH}$ (7.4), with the use of citric acid as a complexation agent. Although prior anaerobic treatment of raw hospital wastewater was able to efficiently remove the biochemical oxygen demand, chemical oxygen demand, total organic carbon, and total nitrogen, the concentrations of the antibiotics ciprofloxacin and sulfadiazine remained at $\mu \mathrm{g} \mathrm{L}^{-1}$ levels, demanding further treatment.

Although the highest rates of degradation of the antibiotics were achieved at $\mathrm{pH} 2.5$, application of the FeCit/ $\mathrm{H}_{2} \mathrm{O}_{2} / \mathrm{UVC}$ treatment at $\mathrm{pH}$ 7.4 resulted in complete degradation of all the antibiotics and disinfection of total coliforms and $E$. coli after $90 \mathrm{~min}$.

The photo-Fenton treatment could also be applied directly to the raw hospital wastewater, without any significant difference in degradation of the antibiotics. In addition, the ability to use solar irradiation is attractive due to the potential savings in the energy costs of photo-Fenton treatment.

The photo-Fenton/UVC process was effective for the treatment of hospital wastewater, where high organic loads and the presence of pharmaceuticals and pathogens can lead to harm to the aquatic environment and human health.

\section{Acknowledgments}

The authors are grateful for financial support provided by the Brazilian agencies CNPq (grants \#151022/2014-3 and \#308649/20150) and FAPESP (grant \#2015/21732-5). The authors also thanks Prof. Felix Reyes and Patricia Braga (GTAF, School of Food Engineering of the University of Campinas) for the isotopically labeled standards supply.

\section{Appendix A. Supplementary data}

Supplementary data associated with this article can be found, in the online version, at http://dx.doi.org/10.1016/j.apcatb.2017.11.021.

\section{References}

[1] S. Kim, D. Aga, Potential ecological and human health impacts of antibiotics and antibiotic-resistant bacteria from wastewater treatment plants, J. Toxicol. Environ. Heal. Part B 10 (2007) 559-573, http://dx.doi.org/10.1080/15287390600975137.

[2] K. Kümmerer, Antibiotics in the aquatic environment - A review - Part I, Chemosphere 75 (2009) 417-434, http://dx.doi.org/10.1016/j.chemosphere.2008. 11.086.

[3] K. Kümmerer, Antibiotics in the aquatic environment - A review - Part II, Chemosphere 75 (2009) 435-441, http://dx.doi.org/10.1016/j.chemosphere.2008. 12.006.

[4] K. Kummerer, A. Henninger, Promoting resistance by the emission of antibiotics from hospitals and households into effluent, Clin. Microbiol. Infect. 9 (2003) 1203-1214, http://dx.doi.org/10.1111/j.1469-0691.2003.00739.x.

[5] J.-R. Yeom, S.-U. Yoon, C.-G. Kim, Quantification of residual antibiotics in cow manure being spread over agricultural land and assessment of their behavioral effects on antibiotic resistant bacteria, Chemosphere 182 (2017) 771-780, http://dx. doi.org/10.1016/j.chemosphere.2017.05.084.

[6] A. Göbel, C.S. Mcardell, M.J.-F. Suter, W. Giger, Trace determination of macrolide and sulfonamide antimicrobials, a human sulfonamide metabolite, and trimethoprim in wastewater using liquid chromatography coupled to electrospray tandem mass spectrometry, Anal. Chem. 76 (2004) 4756-4764, http://dx.doi.org/10.1021/ ac0496603.

[7] P. Verlicchi, A. Galletti, M. Petrovic, D. Barceló, Hospital effluents as a source of emerging pollutants: an overview of micropollutants and sustainable treatment options, J. Hydrol. 389 (2010) 416-428, http://dx.doi.org/10.1016/j.jhydrol.2010. 06.005.

[8] B. Pauwels, F.F. Ngwa, S. Deconinck, W. Verstraete, Effluent quality of a conventional activated sludge and a membrane bioreactor system treating hospital wastewater, Environ. Technol. 27 (2006) 395-402, http://dx.doi.org/10.1080/ 09593332708618651.

[9] P. Verlicchi, M. Al Aukidy, A. Galletti, M. Petrovic, D. Barceló, Hospital effluent: investigation of the concentrations and distribution of pharmaceuticals and 
environmental risk assessment, Sci. Total Environ. 430 (2012) 109-118, http://dx. doi.org/10.1016/j.scitotenv.2012.04.055.

[10] S.K. Behera, H.W. Kim, J.-E. Oh, H.-S. Park, Occurrence and removal of antibiotics, hormones and several other pharmaceuticals in wastewater treatment plants of the largest industrial city of Korea, Sci. Total Environ. 409 (2011) 4351-4360, http:// dx.doi.org/10.1016/j.scitotenv.2011.07.015.

[11] E.M. Golet, A.C. Alder, W. Ginger, Environmental exposure and risk assessment of fluoroquinolone antibacterial agents in wastewater and river water of the glatt valley watershed, Switzerland, Environ. Sci. Technol. 36 (2002) 3645-3651, http:// dx.doi.org/10.1021/es0256212.

[12] E.M. Golet, I. Xifra, H. Siegrist, A.C. Alder, W. Giger, Environmental exposure assessment of fluoroquinolone antibacterial agents from sewage to soil, Environ. Sci. Technol. 37 (2003) 3243-3249, http://dx.doi.org/10.1021/es0264448.

[13] R.H. Lindberg, P. Wennberg, M.I. Johansson, M. Tysklind, B.A. Andersson, Screening of human antibiotic substances and determination of weekly mass flows in five sewage treatment plants in Sweden, Environ. Sci. Technol. 39 (2005) 3921-3929, http://dx.doi.org/10.1021/es048143z.

[14] M. Clara, B. Strenn, O. Gans, E. Martinez, N. Kreuzinger, H. Kroiss, Removal of selected pharmaceuticals, fragrances and endocrine disrupting compounds in a membrane bioreactor and conventional wastewater treatment plants, Water Res. 39 (2005) 4797-4807, http://dx.doi.org/10.1016/j.watres.2005.09.015.

[15] A.J. Watkinson, E.J. Murby, D.W. Kolpin, S.D. Costanzo, The occurrence of antibiotics in an urban watershed: from wastewater to drinking water, Sci. Total Environ. 7 (2008) 2711-2723, http://dx.doi.org/10.1016/j.scitotenv.2008.11.059.

[16] L. Zhao, Y. Ji, J. Yao, S. Long, D. Li, Y. Yang, Quantifying the fate and risk assessment of different antibiotics during wastewater treatment using a Monte Carlo simulation, J. Clean. Prod. 168 (2017) 626-631, http://dx.doi.org/10.1016/j. jclepro.2017.09.065.

[17] P. Xu, M. Janex, P. Savoye, A. Cockx, V. Lazarova, Wastewater disinfection by ozone: main parameters for process design, Water Res. 36 (2002) 1043-1055, http://dx.doi.org/10.1016/S0043-1354(01)00298-6.

[18] G. Hua, D.A. Reckhow, Characterization of disinfection byproduct precursors based on hydrophobicity and molecular size, Environ. Sci. Technol. 41 (2007) 3309-3315, http://dx.doi.org/10.1021/es062178c.

[19] J. Bandara, C. Pulgarin, P. Peringer, J. Kiwi, Chemical (photo-activated) coupled biological homogeneous degradation of p-nitro-o-toluene-sulfonic acid in a flow reactor, J. Photochem. Photobiol. A Chem. 111 (1997) 253-263, http://dx.doi.org/ 10.1016/S1010-6030(97)00249-9.

[20] J. Pignatello, Dark and photoassisted iron $(3+)$-catalyzed degradation of chlorophenoxy herbicides by hydrogen peroxide, Environ. Sci. Technol. 26 (1992) 944-951, http://dx.doi.org/10.1021/es00029a012.

[21] R.F.P. Nogueira, J.R. Guimarães, Photodegradation of dichloroacetic acid and 2, 4dichlorophenol by ferrioxalate/ $\mathrm{H}_{2} \mathrm{O}_{2}$ system, Water Res. 34 (2000) 895-901, http://dx.doi.org/10.1016/S0043-1354(99)00193-1.

[22] A.G. Trovó, S.A.S. Melo, R.F.P. Nogueira, Photodegradation of the pharmaceuticals amoxicillin, bezafibrate and paracetamol by the photo-Fenton process Application to sewage treatment plant effluent, J. Photochem. Photobiol. A Chem. 198 (2008) 215-220, http://dx.doi.org/10.1016/j.jphotochem.2008.03.011.

[23] N. Klamerth, S. Malato, A. Agüera, A. Fernández-Alba, Photo-Fenton and modified photo-Fenton at neutral $\mathrm{pH}$ for the treatment of emerging contaminants in wastewater treatment plant effluents: a comparison, Water Res. 47 (2013) 833-840, http://dx.doi.org/10.1016/j.watres.2012.11.008.

[24] J.A.L. Perini, M. Perez-Moya, R.F.P. Nogueira, Photo-Fenton degradation kinetics of low ciprofloxacin concentration using different iron sources and $\mathrm{pH}$, J. Photochem. Photobiol. A Chem. 259 (2013) 53-58, http://dx.doi.org/10.1016/j.jphotochem. 2013.03.002.

[25] B. Faust, R. Zepp, Photochemistry of aqueous iron(III)-polycarboxylate complexes: roles in the chemistry of atmospheric and surface waters, Environ. Sci. Technol. 27 (1993) 2517-2522, http://dx.doi.org/10.1021/es00048a032.

[26] E.M. Glebov, I.P. Pozdnyakov, V.P. Grivin, V.F. Plyusnin, X. Zhang, F. Wu, N. Deng, Intermediates in photochemistry of $\mathrm{Fe}(\mathrm{III})$ complexes with carboxylic acids in aqueous solutions, Photochem. Photobiol. Sci. 10 (2011) 425-430, http://dx.doi. org/10.1039/COPP00151A.

[27] A. De Luca, R.F. Dantas, S. Esplugas, Study of Fe(III)-NTA chelates stability for applicability in photo-Fenton at neutral pH, Appl. Catal. B Environ. 179 (2015) 372-379, http://dx.doi.org/10.1016/j.apcatb.2015.05.025.

[28] L. Clarizia, D. Russo, I. Di Somma, R. Marotta, R. Andreozzi, Homogeneous photoFenton processes at near neutral pH: a review, Appl. Catal. B Environ. 209 (2017) 358-371, http://dx.doi.org/10.1016/j.apcatb.2017.03.011.

[29] F. Sopaj, N. Oturan, J. Pinson, F. Podvorica, M.A. Oturan, Effect of the anode materials on the efficiency of the electro-Fenton process for the mineralization of the antibiotic sulfamethazine, Appl. Catal. B Environ. 199 (2016) 331-341, http://dx. doi.org/10.1016/j.apcatb.2016.06.035.

[30] E.A. Serna-Galvis, J. Silva-Agredo, A.L. Giraldo-Aguirre, O.A. Flórez-Acosta, R.A. Torres-Palma, High frequency ultrasound as a selective advanced oxidation process to remove penicillinic antibiotics and eliminate its antimicrobial activity from water, Ultrason. Sonochem. 31 (2016) 276-283, http://dx.doi.org/10.1016/j. ultsonch.2016.01.007.

[31] Y. Mameri, N. Debbache, M.el.M. Benacherine, N. Seraghni, T. Sehili, Heterogeneous photodegradation of paracetamol using goethite $/ \mathrm{H}_{2} \mathrm{O}_{2}$ and goethite/oxalic acid systems under artificial and natural light, J. Photochem. Photobiol. A Chem. 315 (2016) 129-137, http://dx.doi.org/10.1016/j.jphotochem.2015.09. 019.

[32] A.G. Trovó, V.A.B. Paiva, B.M. Costa Filho, A.E.H. Machado, C.A. Oliveira, R.O. Santos, D. Daniel, Photolytic degradation of chloramphenicol in different aqueous matrices using artificial and solar radiation: reaction kinetics and initial transformation products, J. Braz. Chem. Soc. 25 (2014) 2007-2015, http://dx.doi. org/10.5935/0103-5053.20140185.

[33] O. González, C. Sans, S. Esplugas, Sulfamethoxazole abatement by photo-Fenton toxicity, inhibition and biodegradability assessment of intermediates, J. Hazard. Mater. 146 (2007) 459-464, http://dx.doi.org/10.1016/j.jhazmat.2007.04.055.

[34] D. Tonon, A.L. Tonetti, B.C. Filho, D. Augusto, C. Bueno, Wastewater treatment by anaerobic filter and sand filter: hydraulic loading rates for removing organic matter, phosphorus, pathogens and nitrogen in tropical countries, Ecol. Eng. 82 (2015) 583-589, http://dx.doi.org/10.1016/j.ecoleng.2015.05.018.

[35] A.D. Eaton, L.S. Clesceri, A.E. Greenburg, Standard Methods for the Examination of Water and Wastewater, 19th ed., American Public Health Association, Baltimore, Maryland, 1995.

[36] M. Gros, S. Rodríguez-Mozaz, D. Barceló, Rapid analysis of multiclass antibiotic residues and some of their metabolites in hospital, urban wastewater and river water by ultra-high-performance liquid chromatography coupled to quadrupolelinear ion trap tandem mass spectrometry, J. Chromatogr. A 1292 (2013) 173-188, http://dx.doi.org/10.1016/j.chroma.2012.12.072.

[37] W.B. Fortune, M.G. Mellon, Determination of iron with o-phenanthroline, Ind. Eng. Chem. Anal. Ed. 10 (1938) 60-64, http://dx.doi.org/10.1021/ac50118a004.

[38] H. Bader, V. Sturzenegger, J. Hoigné, Photometric method for the determination of low concentration of hydrogen peroxide by the peroxidase catalysed oxidation of $\mathrm{N}$, $\mathrm{N}$-diethyl-p-phenylenediamine (DPD), Water Res. 22 (1988) 1109-1115, http://dx. doi.org/10.1016/0043-1354(88)90005-X.

[39] K.D. Brown, J. Kulis, B. Thomson, T.H. Chapman, D.B. Mawhinney, Occurrence of antibiotics in hospital, residential, and dairy effluent, municipal wastewater, and the Rio Grande in New Mexico, Sci. Total Environ. 366 (2006) 772-783, http://dx. doi.org/10.1016/j.scitotenv.2005.10.007.

[40] M. Seifrtová, A. Pena, C.M. Lino, P. Solich, Determination of fluoroquinolone antibiotics in hospital and municipal wastewaters in Coimbra by liquid chromatography with a monolithic column and fluorescence detection, Anal. Bioanal. Chem. 391 (2008) 799-805, http://dx.doi.org/10.1007/s00216-008-2020-1.

[41] A.Y. Lin, Y. Tsai, Occurrence of pharmaceuticals in Taiwan's surface waters: impact of waste streams from hospitals and pharmaceutical production facilities, Sci. Total Environ. 407 (2009) 3793-3802, http://dx.doi.org/10.1016/j.scitotenv.2009.03. 009.

[42] W. Xu, G. Zhang, X. Li, S. Zou, P. Li, Z. Hu, J. Li, Occurrence and elimination of antibiotics at four sewage treatment plants in the Pearl River Delta (PRD), South China, Water Res. 41 (2007) 4526-4534, http://dx.doi.org/10.1016/j.watres.2007. 06.023 .

[43] J. Xu, Y. Xu, H. Wang, C. Guo, H. Qiu, Y. He, Y. Zhang, Occurrence of antibiotics and antibiotic resistance genes in a sewage treatment plant and its effluent-receiving river, Chemosphere 119 (2015) 1379-1385, http://dx.doi.org/10.1016/j. chemosphere.2014.02.040.

[44] A. Gulkowska, H.W. Leung, M.K. So, S. Taniyasu, N. Yamashita, L.M.Y. Yeung, B.J. Richardson, A.P. Lei, J.P. Giesy, P.K.S. Lam, Removal of antibiotics from wastewater by sewage treatment facilities in Hong Kong and Shenzhen, China, Water Res. 42 (2008) 395-403, http://dx.doi.org/10.1016/j.watres.2007.07.031.

[45] J.A.L. Perini, B.C. Silva, A.L. Tonetti, R.F.P. Nogueira, Photo-Fenton degradation of the pharmaceuticals ciprofloxacin and fluoxetine after anaerobic pre-treatment of hospital effluent, Environ. Sci. Pollut. Res. 24 (2016) 6233-6240, http://dx.doi. org/10.1007/s11356-016-7416-4.

[46] S. Sanches, M.T. Barreto, V.J. Pereira, Drinking water treatment of priority pesticides using low pressure UV photolysis and advanced oxidation processes, Water Res. 44 (2010) 1809-1818, http://dx.doi.org/10.1016/j.watres.2009.12.001.

[47] R.R. Giri, H. Ozaki, Y. Takayanagi, S. Taniguchi, R. Takanami, Efficacy of ultraviolet radiation and hydrogen peroxide oxidation to eliminate large number of pharmaceutical compounds in mixed solution, Int. J. Environ. Sci. Technol. 8 (2011) 19-30, http://dx.doi.org/10.1007/BF03326192.

[48] O. Legrini, E. Oliveros, A.M. Braun, Photochemical processes for water treatment, Chem. Rev. 93 (1993) 671-698, http://dx.doi.org/10.1021/cr00018a003.

[49] J. Porras, C. Bedoya, J. Silva-Agredo, A. Santamaría, J.J. Fernández, R.A. Torrespalma, Role of humic substances in the degradation pathways and residual antibacterial activity during the photodecomposition of the antibiotic cipro fl oxacin in water, Water Res. 94 (2016) 1-9, http://dx.doi.org/10.1016/j.watres.2016.02.024.

[50] J. Buschmann, S. Canonica, U. Lindauer, S. Hug, L. Sigg, Photoirradiation of dissolved humic acid induces arsenic (III) oxidation, Environ. Sci. Technol. 39 (2005) 9541-9546, http://dx.doi.org/10.1021/es051597r.

[51] S. Canonica, Oxidation of aquatic organic contaminants induced by excited triplet states, Chimia (Aarau) 61 (2007) 641-644, http://dx.doi.org/10.2533/chimia. 2007.641.

[52] S. Hug, L. Canonica, M. Wegelin, D. Gechter, U. Von Gunten, Solar oxidation and removal of arsenic at circumneutral $\mathrm{pH}$ in iron containing waters, Environ. Sci. Technol. 35 (2001) 2114-2121, http://dx.doi.org/10.1021/es001551s.

[53] R. Zepp, J. Hoigné, H. Bader, Nitrate-induced photooxidation of trace organic chemicals in water, Environ. Sci. Technol. 21 (1987) 443-450, http://dx.doi.org/ 10.1021/es00159a004.

[54] E. Lipczynska-Kochany, J. Kochany, Effect of humic substances on the Fenton treatment of wastewater at acidic and neutral pH, Chemosphere 73 (2008) 745-750, http://dx.doi.org/10.1016/j.chemosphere.2008.06.028.

[55] S. Thiele-Bruhn, I. Beck, Effects of sulfonamide and tetracycline antibiotics on soil microbial activity and microbial biomass, Chemosphere 59 (2005) 457-465, http:// dx.doi.org/10.1016/j.chemosphere.2005.01.023.

[56] L. Aristilde, G. Sposito, Binding of ciprofloxacin by humic substances: a molecular dynamics study, Environ. Toxicol. Chem. 29 (2010) 90-98, http://dx.doi.org/10. 1002/etc.19.

[57] C. Gu, K. Karthikeyan, Sorption of the antimicrobial ciprofloxacin to aluminum and 
iron hydrous oxides, Environ. Sci. Technol. 39 (2005) 9166-9173, http://dx.doi. org/10.1021/es051109f.

[58] F. Polesel, K. Lehnberg, W. Dott, S. Trapp, K.V. Thomas, G.B. Plósz, Factors influencing sorption of ciprofloxacin onto activated sludge: experimental assessment and modelling implications, Chemosphere 119 (2015) 105-111, http://dx.doi.org/10. 1016/j.chemosphere.2014.05.048.

[59] D. Spuhler, A.J. Rengifo-Herrera, C. Pulgarin, The effect of $\mathrm{Fe}^{2+}, \mathrm{Fe}^{3+}, \mathrm{H}_{2} \mathrm{O}_{2}$ and the photo-Fenton reagent at near neutral $\mathrm{pH}$ on the solar disinfection (SODIS) at low temperatures of water containing Escherichia coli K12, Appl. Catal. B Environ. 96 (2010) 126-141, http://dx.doi.org/10.1016/j.apcatb.2010.02.010.

[60] I. García-Fernández, M. Polo-López, I. Oller, P. Fernández-Ibánez, Bacteria and fungi inactivation using $\mathrm{Fe}^{3+}$ /sunlight, $\mathrm{H}_{2} \mathrm{O}_{2}$ /sunlight and near neutral photo-
Fenton: a comparative study, Appl. Catal. B Environ. 121-122 (2012) 20-29, http://dx.doi.org/10.1016/j.apcatb.2012.03.012.

[61] B. Halliwell, J. Gutterridge, Oxygen toxicity, oxygen radicals, transition metals and disease, Biochem. J. 219 (1984) 1-14, http://dx.doi.org/10.1042/bj2190001.

[62] W.A.M. Hijnen, E.F. Beerendonk, G.J. Medema, Inactivation credit of UV radiation for viruses, bacteria and protozoan (oo)cysts in water: a review, Water Res. 40 (2006) 3-22, http://dx.doi.org/10.1016/j.watres.2005.10.030.

[63] N. Klamerth, S. Malato, A. Agüera, A. Fernández-Alba, G. Mailho, Treatment of municipal wastewater treatment plant effluents with modified photo-Fenton as a tertiary treatment for the degradation of micro pollutants and disinfection, Environ. Sci. Technol. 46 (2012) 2885-2892, http://dx.doi.org/10.1021/es204112d. 